\title{
2.8: Designing Visitor Experience for a Narrative-Oriented Exhibition
}

Kseniia Leshchenko

West Virginia University, kl0022@mix.wvu.edu

Follow this and additional works at: https://researchrepository.wvu.edu/etd

Part of the Graphic Design Commons

\section{Recommended Citation}

Leshchenko, Kseniia, "2.8: Designing Visitor Experience for a Narrative-Oriented Exhibition" (2019). Graduate Theses, Dissertations, and Problem Reports. 3806.

https://researchrepository.wvu.edu/etd/3806

This Thesis is protected by copyright and/or related rights. It has been brought to you by the The Research Repository @ WVU with permission from the rights-holder(s). You are free to use this Thesis in any way that is permitted by the copyright and related rights legislation that applies to your use. For other uses you must obtain permission from the rights-holder(s) directly, unless additional rights are indicated by a Creative Commons license in the record and/ or on the work itself. This Thesis has been accepted for inclusion in WVU Graduate Theses, Dissertations, and Problem Reports collection by an authorized administrator of The Research Repository @ WVU. For more information, please contact researchrepository@mail.wvu.edu. 


\title{
2.8: DESIGNING VISITOR EXPERIENCE FOR A NARRATIVE-ORIENTED EXHIBITION
}

\author{
Kseniia Leshchenko \\ Thesis submitted \\ to the College of Creative Arts \\ at West Virginia University
}

in partial fulfillment of the requirements for the degree of

Master of Fine Arts in

Graphic Design

\author{
Eve Faulkes, M.F.A., chair \\ Joseph Galbreath, M.F.A. \\ Kofi Opoku, M.F.A. \\ Gerald Habarth, M.F.A. \\ Department of Art and Design \\ Morgantown, West Virginia \\ 2019
}

Keywords: Stereotypes, Satire, Interactivity, Storytelling, Experience design

Copyright 2019 Ksenia Leshchenko 


\author{
ABSTRACT \\ 2.8 \\ Ksenia Leshchenko
}

This thesis proposes interactive visitor experience with social media and fake news references at 2.8 thesis exhibition at West Virginia University. 2.8 refers to the distance between the United States and Russia borders in the Bering Strait and suggests that switching a point of view helps conflicting groups find common ground. By designing a space in such a way that a visitor constantly faces an alternative point of view, which in this case represents my own, I investigate whether this experience contributes to the viewers' outlook change. Another aim is to see whether adding interactive elements to a show improves the visitor experience. There is much personality put into my work, which results in the use of satire, bright saturated colors and obscure imagery. I used some of my old work in the show to examine how my own perception as a foreigner has changed over the years I lived in the United States. The goal of this exhibition was to challenge visitors' beliefs through historical data and facts, showing that we have more in common than one might think, and it should not be seen as a negative factor. 


\section{TABLE OF CONTENTS}

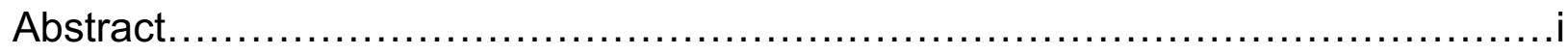

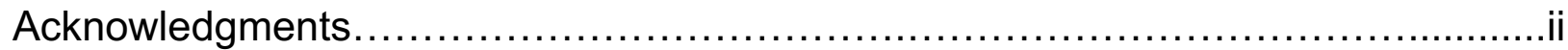

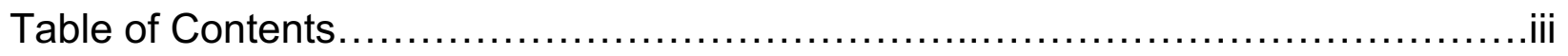

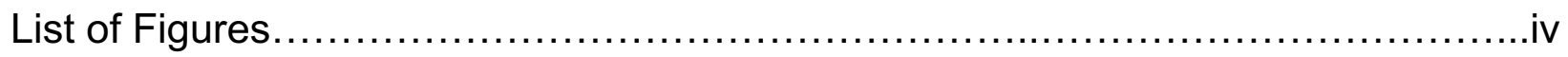

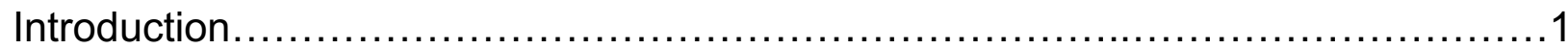

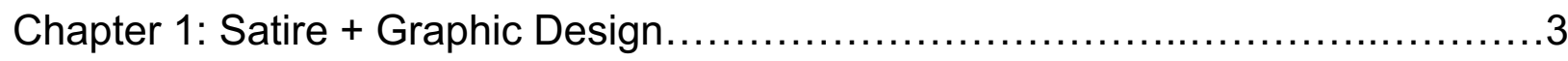

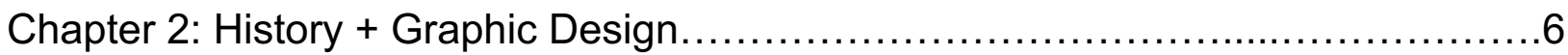

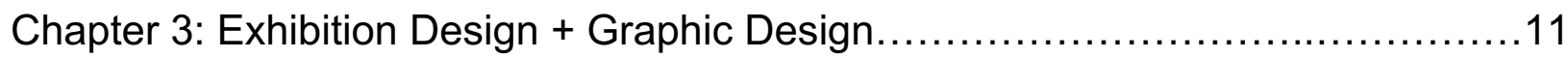

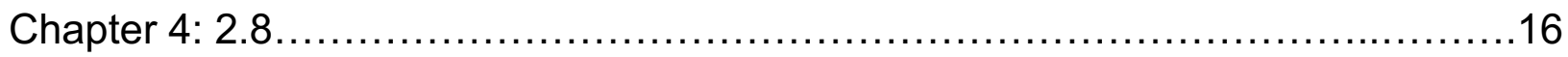

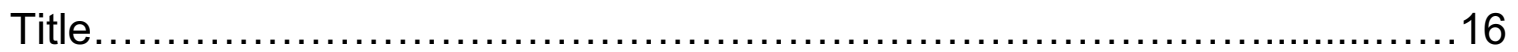

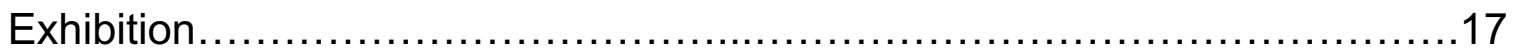

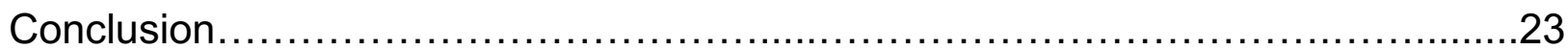

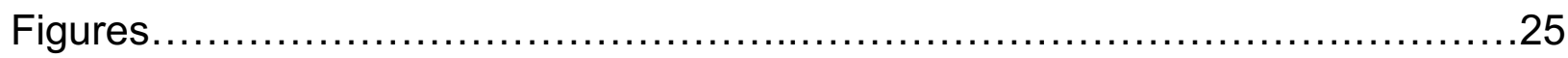

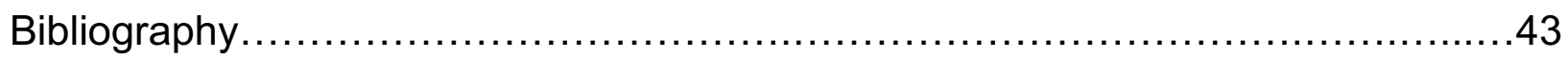

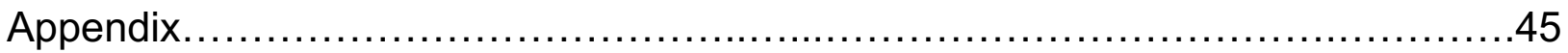




\section{LIST OF FIGURES}

Figure 1. Trump draws memes: The Donald Trump executive order meme is

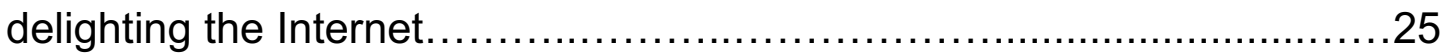

Figure 2. Tucker Viemeister proposes a Nazi-style logo for Donald Trump..........26

Figure 3. Jonathan Barnbrook, outside view of Cruel Designs, $2017 \ldots \ldots \ldots \ldots \ldots . . \ldots 27$

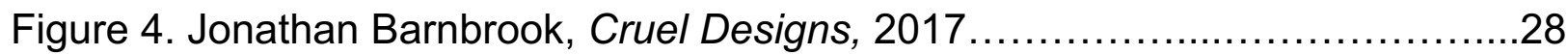

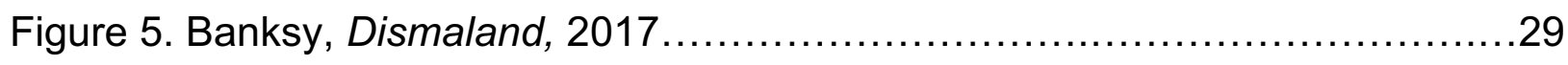

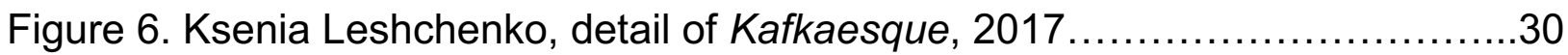

Figure 7. Great Unsolved Mysteries in Canadian History............................. 31

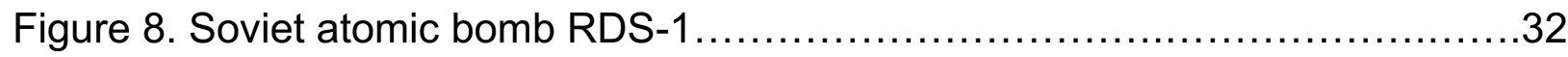

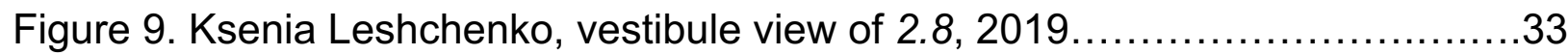

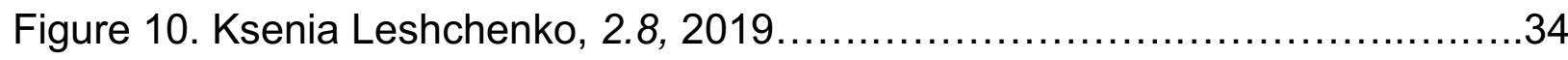

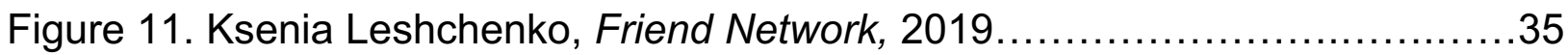

Figure 12. Ksenia Leshchenko, description of Friend Network, 2019...............36

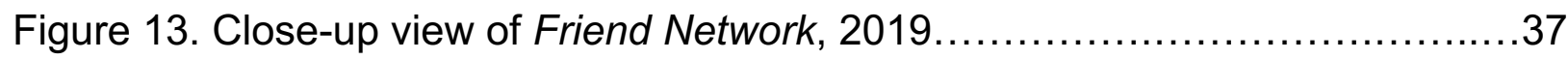

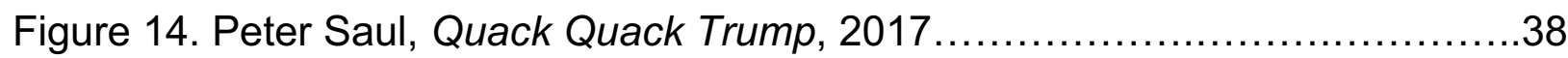

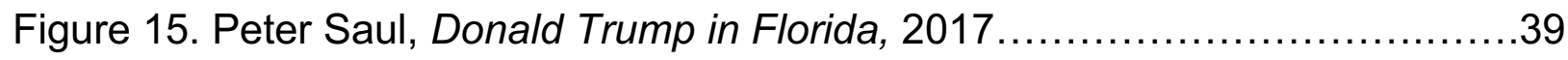

Figure 16. Ksenia Leshchenko, The 10-Year Challenge, 2019..................40

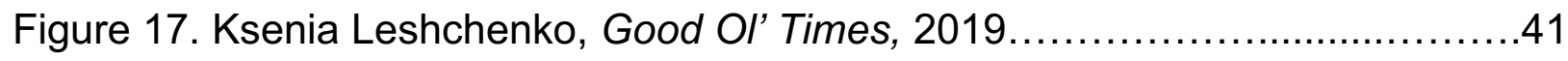

Figure 18. Ksenia Leshchenko, Comments Section, $2019 \ldots \ldots \ldots \ldots \ldots \ldots \ldots \ldots \ldots . \ldots 2$ 


\section{INTRODUCTION}

Being a foreigner anywhere can be quite challenging. But while for some it is just a matter of speaking a different language and overcoming cultural differences, for others this includes dealing with stereotypes, generalization, and prejudice.

While studying in Germany in 2015, right after the Ukrainian-Russian conflict over Crimea took place, I was overwhelmed by the number of political conversations I had to participate in. There was not a single day when I did not have to answer questions about the Russian government, its policies and the reason behind the Crimea annexation. I was convinced that after moving to the United States, this will only get worse. However, I was genuinely surprised after finding out that no one here seemed to care about politics. As an American friend of mine put it then, "Russia is so far away that it does not concern us."

After the 2016 Presidential Election, strong negativity towards Russians arose. Every social connection of someone from the United States to Russians started to be considered a crime. Until then, I had never faced so much hate towards myself and my nation, which I feel strongly connected to. I would treat every hateful comment or uncomfortable question as a free pass to exercise my sarcasm, which one might get sight of in Kafkaesque that became a part of the thesis exhibition. Though I felt like this kind of work needed more context, as one might not be wellinformed on this matter, which causes misunderstanding and potential disagreement. 
Title 2.8 could easily be substituted with "Yes, but..." — the way I would usually start my reply in response to any accusations of someone from Russia having ties to America. This trend of seeing any communication between the countries as negative and threatening only arose a few years ago, but has already started to be perceived as if it has always been like this. My intention was to show that even current politicians, who voice strong objection to the other country and its policies, actually had a different opinion about their opponents not so long ago, and the public did not see their past sympathy as a negative factor. Additionally, I suggest that we should not see each other merely as representatives of the countries we come from, but rather as individuals who have their own opinions that might even contradict our governments' agendas.

However, I had to accept the fact that conversations about Russia often cause a strong negative reaction. With that in mind, I had to design a space that calls for dialogue and does not evoke unpleasant emotions. By using satire, exhibition design techniques and making educational exhibits (e.g. Bromance, Caught or Not) interactive, I examine how this affects visitor experience in comparison to a traditional gallery exhibition. 


\section{CHAPTER 1: SATIRE + GRAPHIC DESIGN}

Satire has always played an important role during times of political crisis. The most recent example is the rise of satire in design in 2016, during and after the presidential elections. Social media alone were a crucial part in fostering the creation of political parodies that quickly spread out as GIFs, memes and satirical fake Twitter accounts, mocking candidates. One of the most popular parodies is the video of Donald Trump signing an executive order, days after his inauguration, and showing the documents to the cameras (fig. 1).

AIGA Eye On Design writer Margaret Andersen emphasizes the changing role of satire in the modern realities:

"And while we can't rely on enamel pins to sway political policy or election results, it's now more apparent than ever that democracy needs satirists to challenge the status quo and the current spread of disinformation, nationalism, populism, and fear ${ }^{1}$."

Along with internet users, graphic designers, too, widely use satire as a way to resist the government. In 2016, months before Donald Trump became president, industrial designer Tucker Viemeister created a logo (fig. 2) that imitates the Nazi party symbol to reflect the "correlation between Trump's racist hate mongering and

${ }^{1}$ Andersen, Margaret, "How Do You Design for an Era That's Too Absurd to Parody?", AIGA Eye on Design, March 17, 2017, Accessed November 20, 2018, https://eyeondesign.aiga.org/how-do-you-design-for-an-era-thats-too-absurd-toparody/\#:post_56256 
the Nazis." ${ }^{2}$ In 2015, Jonathan Barnbrook, British graphic designer known for his works for Adbusters and Brandalism, collaborated with Banksy to work on Cruel Designs that became a part of Dismaland. Set up as a museum inside a windowless bus, the purpose of the exhibit was to discuss the role of design for social control. (fig. 3, 4 \& 5) Barnbrook mentions that "the museum included items that were specifically designed to control, hurt, or even kill you, and the top of the bus was lined with fake adverts addressing some of the objects on display as well as wider themes of injustice, consumerism, and cruelty." ${ }^{3} \mathrm{He}$ explains that satire is important not only because it serves as a form of catharsis, but because it "highlights how ridiculous normality is. We have people trying to normalize the Trump situation, and it isn't normal, and satire can open your eyes to that."

Just like Barnbrook uses satire to show people that something that is being normalized is not in fact normal, I try to do the exact opposite with my work. From my perspective, Russia's demonization that started in 2014 and was pushed to the extremes two years later, does not have enough reasoning behind it. The current American leaders are accused of having ties to Russia, like this has never been the

${ }^{2}$ Fairs, Marcus, "Tucker Viemeister proposes Nazi-style logo for Donald Trump," Dezeen, January 31, 2017, Accessed November 20, 2018, https://www.dezeen.com/2017/01/31/nazi-logo-donald-trump-tucker-viemeister-designgraphics-usa-news/

${ }^{3}$ Barnbrook, Jonathan, "Banksy's Dismaland: Cruel Designs," Barnbrook, Accessed November 20, 2018, http://www.barnbrook.net/work/dismaland-cruel-designs/

${ }^{4}$ Ibid. 
case before. My intention is to show people the way I see this situation, and humor and satire help to talk to viewers without being didactic.

Satire essentially is the language of Kafkaesque. It does not only serve as a hook to attract one's attention, but also allows me as a designer to bring up controversial topics without negativity. Instead of explaining how media present the same information differently, which affects a reader's intake from an article, I put two headlines from the articles discussing the same issue side-by-side. (fig. 6) Not being satirical on their own, these headlines placed next to each other create resonance and make the spread read as a meme. Thus, a viewer is able to make the aforementioned conclusion himself, without a designer's guidance. 


\section{CHAPTER 2: HISTORY + GRAPHIC DESIGN}

Philosophies of experiential education and constructivism gave rise to the idea that interactivity should improve visitor learning at the gallery and museum experience. John Dewey introduced an experiential philosophy for education, placing extra emphasis on the importance of experiences for challenging or supporting a learner's previous understanding. Jean Piaget put great store on interactions with the material world because they provoked learners either to assimilate new knowledge into their existing conceptual structure or to accommodate new, conflicting ideas by restructuring their previous understanding. Both philosophies state that people learn by building their own understandings based on experience, and that educational systems should offer experiences to support learning.

User experience design and interactive design, in particular, could both be successful tools for history education, but these are only rarely used in academia. One of the projects that demonstrate the efficiency of using design in history education is Great Unsolved Mysteries in Canadian History. (fig. 7) It is designed as a digital game-based learning website, where students engage in solving presented mysteries by examining real historical documents and records. Creators also provide the first part of a story and the tools for students to write the ending. Each of the twelve mysteries involves some of the big issues that concern historians: race, gender, ethnicity, immigration, religious intolerance, terrorism, war, climate change, aboriginal-non-aboriginal relations, wrongful convictions, and child abuse, to name a few. All the mysteries presented in the game were chosen because there is no 
single solution. In all cases, students have to assemble a narrative out of diverse, unordered and even contradictory evidence in a way that makes sense and shows that their solution is more plausible than the alternatives.

Written as a series of hints rather than a linear narrative, the game is designed to encourage students to do historical research on their own, and develop rational thinking by examining artifacts, archive documents, maps, photos, and articles. Unlike traditional textbooks, where students are provided with ready-made solutions, the website lets them think critically about historical events and the evidence surrounding it. ${ }^{5}$

History of something is a common exhibition topic. Companies and big corporations, such as Nike and Coca-Cola, employ exhibits to talk about a brand's history, as a way to promote their product. "Tribal" museums, such as the Jewish Museum and the National Museum of African American History and Culture are dedicated to the enjoyment, understanding, and preservation of their artistic and cultural heritage, and encourage their visitors to learn how rich and diverse a particular culture is. Richly equipped with interactive exhibits, such museums create environments for a deeper understanding of raised issues through experiential learning. An example of such experience can be the Rossiya Delaet Sama / RDS exhibition at the Polytechnic Museum at VDNKH in Moscow, Russia. One of its most notable pieces is a model of the first Soviet atomic bomb RDS-1, created in 1949.

5 "Great Unsolved Mysteries in Canadian History. Recipient of the 2008 Pierre Berton Award," Canada's History, July 1, 2008, Accessed April 8, 2019, https://www.canadashistory.ca/awards/governor-general-s-history-awards/awardrecipients/2008/great-unsolved-mysteries-in-canadian-history. 
(fig. 8) It is not only presented in full-scale but more importantly, the visitors can feel what it is like to experience a bomb's explosion. While standing on a special platform in front of the exhibit, a visitor has the same experience as he would have if an atomic bomb exploded in a 20-kilometer radius (about 12 miles). The "explosion" is imitated by an outburst of light, loud noise, and the floor vibration. This way of teaching about atomic bombs and their performance is more demonstrative than an attempt to describe it in a textbook.

Historical research was a big part of the exhibition making. The idea for a thesis project that would show that there is more to Russia-America relations than the 2016 Interference scandal, and that we used to be more connected to each other, came to me after reading Ivan Kurilla's Zaklyatye druzia: Istoria mneniy, fantazii, kontaktov, vzaimo(ne)ponimania Rossii i SShA (Frenemies: History of opinions, phantasies, contacts, mutual (mis)understanding of Russia and the USA). Kurilla, a professor of History and International Relations at European University in St. Petersburg, Russia, discusses the history of U.S.-Russia relations, and why we are so similar, even though our governments are trying to prove the opposite. Friend Network owes its existence to the research made and documented by Ivan Kurilla.

Friend Network is closely connected to the notion of a stereotype. According to Walter Lippmann, an American writer famous for introducing the concept of Cold War and coining the term stereotype in the modern psychological meaning, a stereotype can be defined as a negative generalization used by an in-group (Us) about an out-group (Them). He called these mental constructs "pictures in our 
heads." ${ }^{6}$ My role as a designer was to embrace the stereotypes about Russians that exist in Western society and try to disprove some of them. As mentioned by Charles Raminez Berg, a professor of Film Studies at the University of Texas, one of the eleven theses about stereotypes states that they are conventionally ahistorical, selectively omitting the out-group's social, political, and historic group history. ${ }^{7} \mathrm{By}$ creating a map that reveals connections between people, I show that the stereotype of Russians and Americans being each other's worst rivals has no historical basis.

The 10-Year Challenge and Good Ol' Times continue to further discuss the topic of stereotypes, past connections, and collaborations between Americans and Russians, and how mass media seem to erase this information from our memory over time. They both work as "supporting materials" for the Friend Network, as after seeing the latter, one might think that it lacks proof. Actual historical photos, used in both \#3 and \#4, bring visual data into the show to make it more trustworthy.

Interactive game Bromance can be compared to Great Unsolved Mysteries in Canadian History, discussed in the second chapter. Instead of reading about past interactions between politicians, players have to act on someone else's behalf, which gives a better understanding of why certain political leaders are friends or enemies with one another. However, there is an extensive historical reference each time a player interacts with the game. To explain why a certain answer is correct or

${ }^{6}$ Lippmann, Walter, Public Opinion, New York: Macmillan, 1922; rpt: Toronto: Free Press, 1965, 88.

${ }^{7}$ Katz, Daniel, Kenneth Braly, "Racial Prejudice and Racial Stereotypes," International Social Science Bulletin 3 (1951): 505-515. 
not, I provided extracts from articles, collected from various sources (The Guardian, The New York Times, NPR, to name a few), and actual quotes from past conversations that the politicians participated in. Caught or Not, a board game where participants get to guess whether a particular news headline indicates fake news, has similar gameplay; a player interacts with the game first, and then reads the supporting article. A source of the article is mentioned on the bottom of every game card as a link to a website, where a player can become informed even better about fake news and articles appearing in the game. 


\section{CHAPTER 3: EXHIBITION DESIGN + GRAPHIC DESIGN}

Museums have included new media and technologies into their exhibitions to compete with other sources of information and recreation, as well as technological advancement. ${ }^{8}$ This inclination towards the integration of technology focuses on incorporating immersive and sensory-stimulating qualities within an exhibition to achieve an experiential appeal. ${ }^{9}$ Because of its prioritization of entertainment over education, this practice is considered as market-driven in, and is often referred to as "edutainment or infotainment". ${ }^{10}$

Exhibition design combines communication design and the built environment together, which creates environments that communicate with viewers. Exhibition design is a compound process of integrating different media, such as graphic design, digital media, lighting, audio, interior design and, architecture.${ }^{11}$ Exhibition design can be employed in public spaces, such as art galleries, museums, and showrooms. Created exhibition environments are usually located in places where

${ }^{8}$ Alexander, E. P., Mary Alexander, Museums in motion: An introduction to the history and functions of museums, Lanham: AltaMira Press, 2008.

${ }^{9}$ Naparat, Napapong, "Museum Exhibition: Investigating the Use of Design Elements in Narrative-oriented Exhibitions - a Case Study of the Canadian War Museum's Permanent Exhibition," master's thesis, Carleton University, Ottawa, Canada, 2010, ISBN: 978-0-494-71727-1.

${ }^{10}$ Genoways, Hugh, Museum philosophy for the twenty-first century, Lanham: AltaMira Press, 69-78.

${ }^{11}$ Skolnick, Lee, Jan Lorenc, What Is Exhibition Design? UK: RotoVision, 2008. 
intensive social interaction can be arranged. A diverse group of visitors interacting with the exhibition environment is what makes exhibition design unique and dynamic, but it is also what sets rules for designers and establishes the need to identify who their future audience is. "It is important to work with a client to determine the types of visitors they already attract, as well as those they want to bring in." ${ }^{12}$ People tend to behave and react differently, depending on their cultural background and experience. When designing for various groups, a designer must present content and communicative techniques in multiple layers, so that every group of visitors is able to participate simultaneously.

The interpretation of exhibition design is reevaluated over time. Instead of the collections and particular exhibits on the display, exhibitions are now judged based on the quality of the presentation and the story. Today storytelling has become a powerful tool of communication. Exhibition design has made a shift towards immersive environments and large-scale presentations, both of which help tell stories by creating emotional and sensory experiences, enriched by modern technological tools, such as touchscreen kiosks, digital devices, and applications. Thus, participatory and experience design both serve exhibition designers to enhance visiting experiences, especially with the use of interactive technologies that make static exhibitions dynamic. ${ }^{13}$ This allows museums and galleries to create

${ }^{12}$ Skolnick, Lee, Jan Lorenc, What Is Exhibition Design? UK: RotoVision, 2008.

${ }^{13}$ Liu, Kegeng, "Designing visitor experience for open-ended creative engagement in art museums: A conceptual multi-touch prototype design," master's thesis, lowa State University, lowa, 2013, Graduate Theses and Dissertations, 13559. 
engaging educational exhibits. "The desire to be surrounded by a story in a public space, to be told stories dynamically, and to have an interactive experience blended with real environments will forever drive design decisions." ${ }^{14}$

Developments of society and technology instigated the growth of popularity and influence of interactive technologies in exhibition design. Museums and galleries treat digital interactions as important tools that improve the interactivity of visitor experience. ${ }^{15}$ Creating an experience through the use of interactive technologies and visual storytelling can not only make exhibits entertaining to visitors but foster social curiosity. Interactive screens and multi-touch technologies have the ability to attract teenagers and children, a younger audience that museums and galleries usually have trouble reaching. ${ }^{16}$ These technologies are successfully used in science and natural history museums, thus it is likely that art galleries and museums could successfully utilize this technology.

Interactive exhibits did not start only after the invention of computers with touchscreens and Internet. Their history can be traced back to 1889 and the foundation of Urania society in Berlin, the aim of which was to communicate the most recent scientific findings and popularize science among a broad audience. In

${ }^{14}$ Skolnick, Lee, Jan Lorenc, What Is Exhibition Design? UK: RotoVision, 2008.

${ }^{15}$ Liu, Kegeng, "Designing visitor experience for open-ended creative engagement in art museums: A conceptual multi-touch prototype design," master's thesis, lowa State University, lowa, 2013, Graduate Theses and Dissertations, 13559.

${ }^{16}$ Marshall, P., Morris, R., Rogers, Y., Kreitmayer, S., \& Davies, M, Rethinking 'multiuser': An in-the-wild study of how groups approach a walk-up-and-use tabletop interface, New York: ACM, 2011. 
order to achieve this, they built what is now known as the "first science center," with a scientific theater, public observatory, and visitor-activated models, which was later popularized in the 1960s in the United States. ${ }^{17}$ Interactive exhibitions usually make an attempt to connect with viewers by either representing their cultural background or through creating open-minded narratives. For instance, some shows have visitor feedback or even their own labels being incorporated into the exhibition space. ${ }^{18}$ Another approach towards museum interactivity is "play", which integrates games, interactions and learning to create immersive visiting experiences. ${ }^{19}$ Games enable discovery and also allow the museum to become a social space so that it can facilitate co-experience. In games, the player is more important than the objects in the context of the museum. "Often games enable the audience to be in charge, gaining a closer relationship to the museum objects or stories". ${ }^{20}$

According to some researchers, successful visitor learning can be achieved by helping "bridge the original contexts of museum objects with visitors everyday lived context." ${ }^{21}$ The majority of pieces in 2.8 refer to social media platforms. This

17 "Die Urania. Wissenschaftliche Bildung für alle Bürger zu vermitteln," UraniaBerlin, Accessed April 9, 2019, https://www.urania.de/die-urania

${ }^{18}$ Nashashibi, Salwa Mikdadi, Visitor-written labels in US art museums, Orinda: JFK University Press, 2002.

${ }^{19}$ Beale, Katy, Museums at Play, Edinburgh, UK: MuseumsEtc Ltd., 2011.

20 Ibid.

${ }^{21}$ Falk, H. John, Learning from the Museum, Walnut Creek: AltaMira Press, 2000. 
puts visitors back into a mundane context, and also improves visitor experience. As viewers are familiar with social media interfaces and how they behave, they do not have to spend time figuring out the logic of a particular exhibit and how it works. For instance, the Bromance interface is similar to Tinder, therefore people who have had experience using dating applications did not seem to have a problem interacting with the exhibit. In reality, Bromance, along with a board game Caught or Not, described on page 21 , has gotten the most feedback. This supports the claim that having interactive components in an exhibition adds to the visitor experience. Viewers enjoy being directly involved by interacting with exhibits. However, adding a tutorial on how to use the app would improve experience of visitors above 35 years old, as it is not particularly common among people of this age to use dating apps. ${ }^{22}$ They are not as familiar with a "swipe culture" as people under 35 , which creates confusion in interacting with the app interface.

${ }^{22}$ Iqbal, Mansoor, "Tinder Revenue and Usage Statistics (2018)," Business of Apps, February 27, 2019, Accessed April 10, 2019, http://www.businessofapps.com/data/tinder-statistics/. 
CHAPTER 4: 2.8

Title

2.8 is a reference to the distance between the Diomede Islands, which are separated by the border between Russia and the United States. The Russian island of Big Diomede and the U.S. island of Little Diomede are roughly $2.8 \mathrm{mi}$ apart at the closest point. The Islands are often mentioned as likely intermediate stops for the hypothetical bridge or tunnel (Bering Strait crossing) spanning the Bering Strait. During winter, an ice bridge usually spans the distance between these two islands. Therefore, during such times, it is theoretically possible (although not legal) to walk between the United States and Russia. This bridge is also often referred to as the "Ice Curtain". However, in 1987, Lynne Cox swam from one island to the other and was congratulated by both Mikhail Gorbachev and Ronald Reagan for her feat. At the signing of the INF Missile Treaty at the White House, Gorbachev made a toast. He and President Reagan lifted their glasses and Gorbachev said: "Last summer it took one brave American by the name of Lynne Cox just two hours to swim from one of our countries to the other. We saw on television how sincere and friendly the meeting was between our people and the Americans when she stepped onto the Soviet shore. She proved by her courage how close to each other our peoples live".

So, sometimes switching a point of view makes it possible to find common ground. In my exhibition, I wanted to show that Russians and Americans have more intersections than one might think today and to dispel the myth disseminated by the media that we have always been each other's worst rivals. 


\section{$\underline{\text { Exhibition }}$}

At the vestibule, following the entrance to the gallery, a viewer encounters the first Russian-American interaction of the show-an imaginary dialogue between two American people and myself. (fig. 9) Designed as a social media dialogue, it fosters people's interest in following the conversation, as this way of organizing an exhibition's description is unconventional in a gallery setting. It also connects to the other pieces in the show, all of which refer to any kind of a social media platform.

Then, the pre-determined visitors' path is suggested by four key elements:

1. The numbers near every piece;

2. The catalog that suggests the same path;

3. The shape of the gallery, with a ramp leading to the first piece;

4. The bold colors of the first piece.

The first piece is the highlight of the show, immediately grasping visitors' attention right after entering the gallery. As one walks into the gallery space, he encounters a bright yellow wall with multiple pieces on it (fig. 10). Observation of the visitors' behavior has shown that the vast majority of people examine Friend Network first unless there is an obstacle (e.g. a crowd blocking the passage). About one-third of the visitors used catalogs to navigate the space and especially the first piece, as all the information about the connections between the people appearing on the wall is concentrated there. The figures in the catalog are put in alphabetical order without separating them based on their nation of origin-they coexist on the pages altogether, without anyone being considered more or less valuable. 
Friend Network is the first and major piece in the show. It is an essential starting point in a visitor's journey, as it is here where one learns about the people discussed in the exhibition and how they connect to one another. (fig. 11, 12) It is a map of historical connections — old and more recent — between Russians and Americans. For easier recognition, all historical figures of American origin are pictured in blue inside a hot pink triangle frame, and Russians are in a square frame, colors reversed. (fig. 13) Using the same colors and making all figures the same size make them equal without distinguishing any particular nation or person. The only figure whose image is larger than the frame surrounding him is Vladimir Putin. This is done intentionally, and not to simply attract one's attention, but to improve the visitor experience. As there is no starting or end point on the map, making one of the figures slightly different than the rest helps viewers find a path to follow. This seemed to be the problem at the early stages of developing the exhibition for those who saw intermediate results. One of these early viewers was Peter Saul, a painter and one of the fathers of the Pop Art movement, whose recent work such as Quack, Quack Trump or Donald Trump in Florida, along with his 2017 show Fake News at Mary Boone Gallery in New York has been inspiring to me since I first came across his work in my Contemporary Art History class. (fig. 14, 15) Saul, who just happened to get back from Russia, gave a lecture at the WVU College of Creative Arts and met with me and a few graduate students for one-on-one critiques. He was excited about my work in general, particularly enjoyed Kafkaesque zines, and told that Friend Network is "the best work among the similar ones of the same topic" he has ever seen. While being flattered, I could not help but see how lost he was in terms of 
finding a way to approach the map and follow its content. Being visually interesting, Friend Network lacked a sense of logic, making it a confusing experience for a viewer. Another person thought that the map was similar to a board game path that one had to follow exactly in order to finish, which evidently was not the case. I attempted to make a few figures on the map unique, but abandoned this idea, as having more than one "entry point" is similar to having none. Leaving only Vladimir Putin's image unique also creates a slight resonance, as one might expect to see his figure being connected to Donald Trump, who is intentionally excluded from the network to avoid visitors making false conclusions about the exhibition's purpose.

Friend Network, as mentioned in its description, is also an attempt to look at people as people rather than representatives of their home countries. In a multicultural world, where many advocate for a "global citizenship" concept, some still find it odd that people of different origin can be friends strictly because of their personal interests, not for their governments' profit. In this sense, the piece is closely connected to Bromance, a Tinder-like interactive game, where a player acts on one of the politicians' behalf and makes a conversation with others to find a "significant other" for his character. The conversations in the game are based on real events that were covered by mass media, however the game dialogues are frivolous and playful, acting as hooks to make players curious enough to read the information they will be given after choosing an answer - that is, a real article, explaining why a particular answer is correct or not. The wording chosen for the game dialogues imitates the way real users would talk to each other on Tinder or any online-dating platform. Just as in Friend Network, this is an effort to take the politicians out of their 
usual context and look at them as regular people, who have personal connections that sometimes have nothing to do with their job.

Following Friend Network and Bromance, both of which refer to some social media platforms, The 10-Year Challenge is a reference to a social media "challenge" that quickly became a trend in early 2019. Just like during the challenge itself, when people were posting photos of themselves from ten years ago to show everyone how they had changed over the past decade, this piece is dedicated to showing how much our relationship has changed since 2009. (fig. 16) Good Ol' Times is a series of photographs directly related to the first piece in the show. It shows the relationships between the people appearing on Friend Network. Color choices coincide with the object of reference; photographs are desaturated, and human figures are colored and framed based on their national origin, just like on the network of connections. (fig. 17) Made as Instagram posts, they do not only put historical figures into a contemporary context, but open a discussion about news trustworthiness. While it is obvious that people such as Joseph Stalin, Walt Disney or any other person from the twentieth century could not make these social media posts, it is not so clear when looking at people from the twenty-first century, such as Dmitry Medvedev or Arnold Schwarzenegger. Seeing the posts as a set allows the viewer to compare each individual one to the others and make a conclusion that these are not real social media publications, as opposed to encountering a single piece.

The topics of trustworthiness and reputability of news sources are further discussed in Caught or Not and a series of zines Kafkaesque. These works reflect 
my perception of what it is like to carry the burden of being a foreigner in a country that considers your motherland as an enemy. For me, every piece of information that I receive on a daily basis from news resources is double sided, thus unclear and distorted. However, I am still hoping to see the truth, which apparently lies somewhere in between. These mixed feelings and confusion going through my mind dictated the esthetics of Kafkaesque - a series of publications, which raise the issue of disinformation and misinterpretation. By talking about specific events and the way they were presented through mass media, I am trying to show different ways of interpreting the same issue and shed a light on common misconceptions. I do not expect readers to change their minds - my goal is to make them question truthfulness of the information they receive daily. Mounted to the ceiling on a bungee cord, they, together with the board game Caught or Not bring additional interactivity and visitors' engagement into the show.

When it comes to getting a political message across, designers, rather than directly designing the messages themselves, may also create the formats to best channel them. ${ }^{23}$ Comments Section, the final piece of the show, is an interactive wall, where visitors are able to react to the exhibition, just like they would have on social media, through the form of reaction stickers or comments. (fig. 18) This engaging environment, where people are able to create any type of content they want, is similar to the early stage of the Occupy Wall Street movement. In the

${ }^{23}$ Metaheaven, Can Jokes Bring Down Governments? Memes, Design and Politics, Moscow, Russia: Strelka Press, 2014. 
beginning, it existed as an online text tool, which was designed to post snippets of computer code posted by programmers. Eventually, it became a platform that hosted hackers posting revolutionary content: not just code, but leaked data, press releases and news. Such tools, when produced by designers, instigate invention of new meanings, new intents, and new messages. ${ }^{24}$ Comments Section, in a way, was a social experiment of what people can write when the addressee is not watching, and feedback can be left anonymously. While it was a little risky, as any potential foul language would have been exposed to the public for up to 8-10 hours, depending on when it had been left, which is especially undesirable in an academic institution, no issues occurred. An unexpected but pleasant outcome of this experiment was that people did not only leave their reactions to the show addressed to me, but also reacted to other visitors' comments. All the collected responses were recorded and listed in the appendix.

${ }^{24}$ Metaheaven, Can Jokes Bring Down Governments? Memes, Design and Politics, Moscow, Russia: Strelka Press, 2014. 


\section{CONCLUSION}

The aim of the research was to investigate whether using interactive elements in a show improves the visitor experience. For this purpose, the thesis exhibition 2.8 was installed in the Paul Mesaros Gallery at West Virginia University in March of 2019. To achieve the set goal, both non-interactive and interactive works were exhibited, to measure if the latter affect visitors.

Including interactive elements into the show undoubtedly added to the visitor experience, based on the received feedback from people of both academic and nonacademic backgrounds. Leaving an opportunity for viewers to express themselves by contributing to Comments Section, while being risky, turned out to be a successful experiment, which could not have been if there were any restrictions for visitors affecting what they are allowed to write. Having a catalog and numbering every piece to suggest a path through the show helped visitors to navigate the space in a logical order, from a broader Friend Network to more specific showpieces, each adding another layer of information and expanding visitors' knowledge about the issues raised in Network.

For the exhibition part of the research, my goal as a designer was not to to be didactic and tell people about my vision of the all-time low and deteriorating America's relationship with Russia, but rather to put the viewers into my shoes and show the issues affecting both nations as I see them. A combination of pieces based on my personal experience (e.g. HAWT Calendar, posters) and works showing my perspective (e.g. Friend Network, Kafkaesque) creates a complete picture of my 
foreign self dealing with stereotypes, double standards, and prejudice. It is not me telling the viewers that they should not act a certain way - it is they who come to this conclusion themselves, without being lectured. It is having a certain experience that helps them come to the conclusion. By providing viewers with this experience, I was investigating whether it contributes to a change in their perspective of RussiaAmerica relations. According to the responses on the Comments Section piece, as well as those received in person, most visitors found the exhibition thoughtprovoking, which is a small step in a complicated process of changing one's perspective. 


\section{FIGURES}

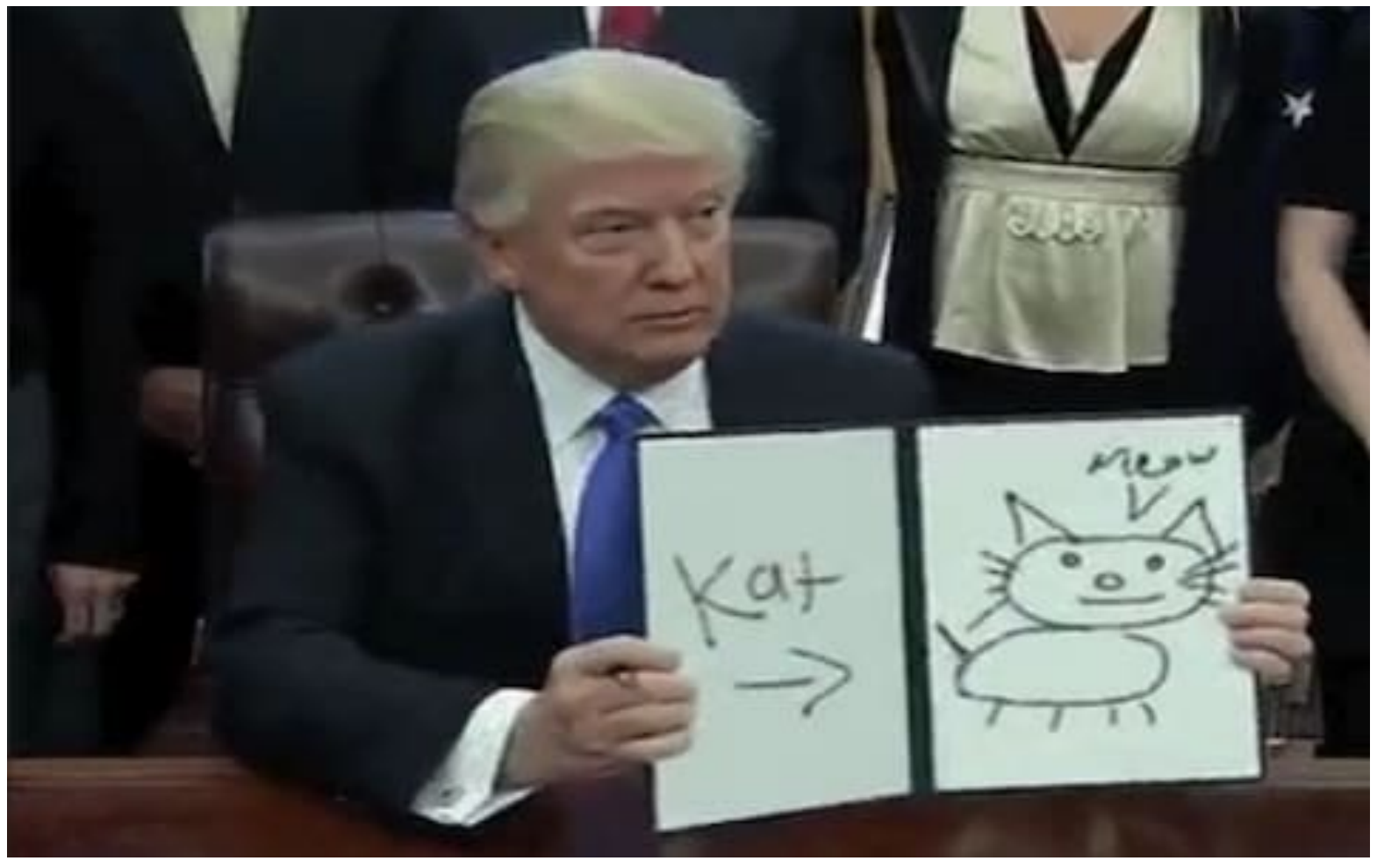

Figure 1. Trump draws memes: The Donald Trump executive order meme is delighting the Internet

Twitter/@TRUMPDRAWS

Reproduced from https://twitter.com/trumpdraws

(Accessed April 12, 2019) 


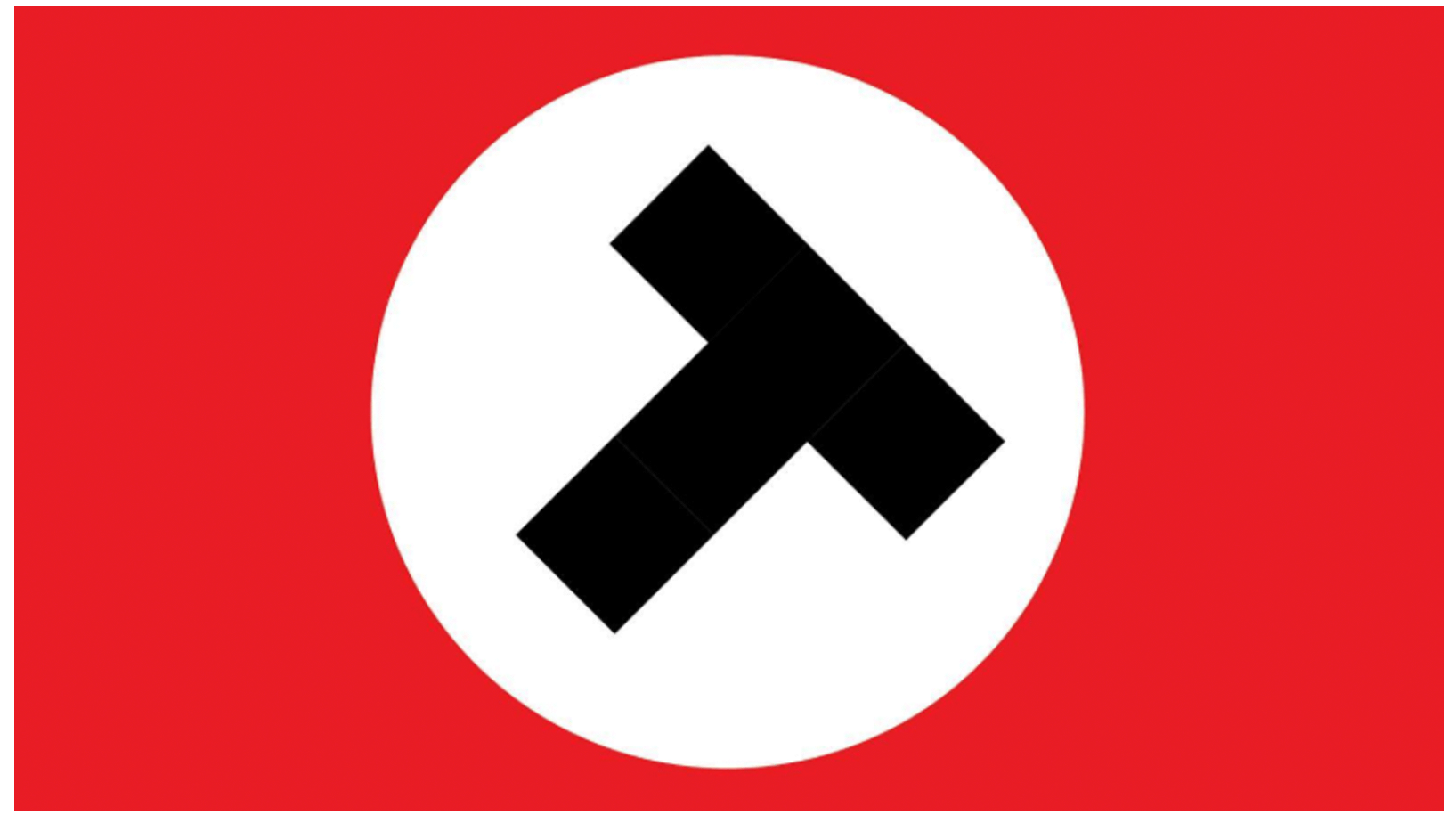

Figure 2. Tucker Viemeister proposes a Nazi-style logo for Donald Trump. Dezeen

Reproduced from https://www.dezeen.com/2017/01/31/nazi-logo-donald-trumptucker-viemeister-design-graphics-usa-news/

(Accessed April 16, 2019) 


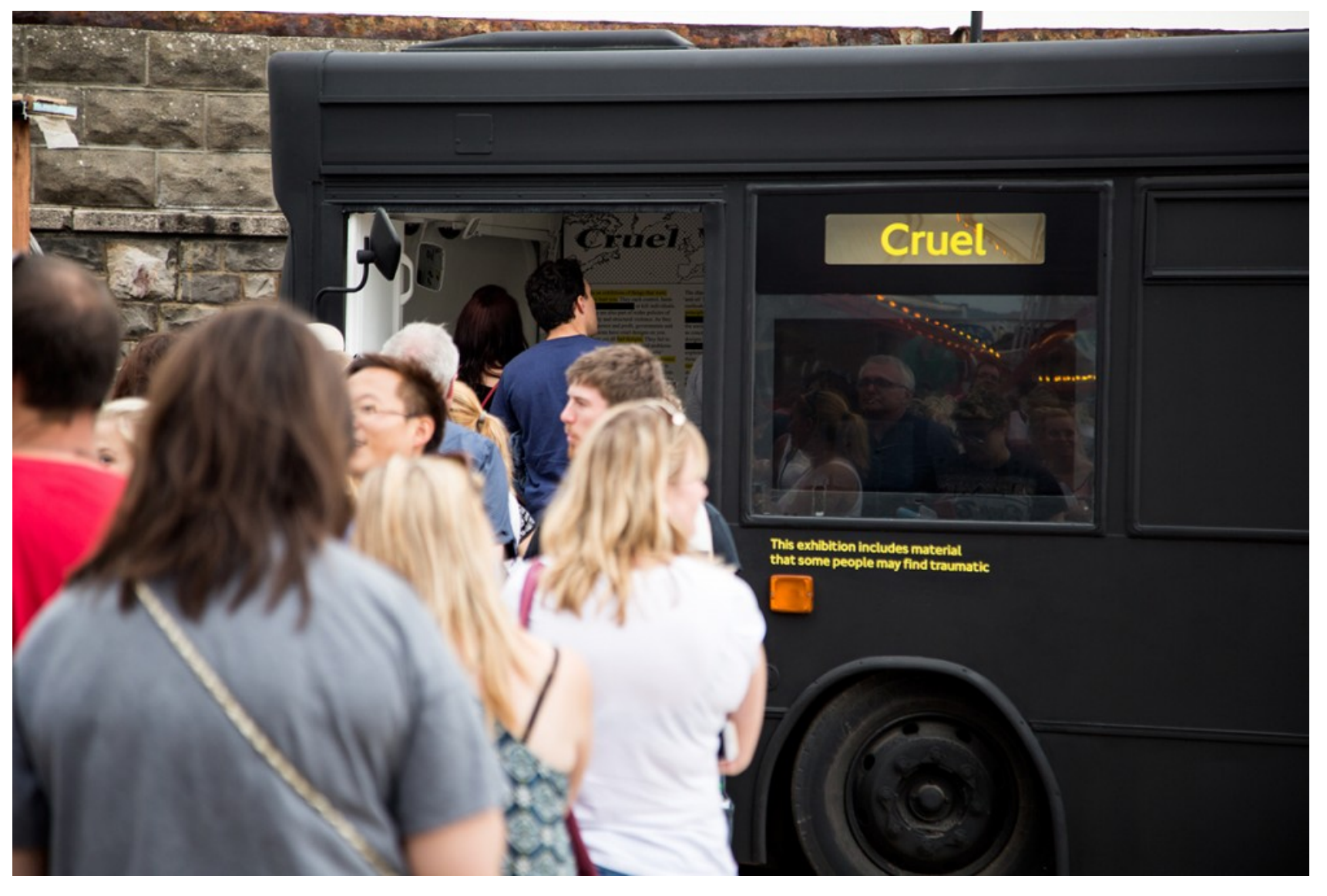

Figure 3. Cruel Designs

Outside view

Jonathan Barnbrook

2017

Reproduced from http://www.barnbrook.net/work/dismaland-cruel-designs/

(Accessed April 17, 2019) 


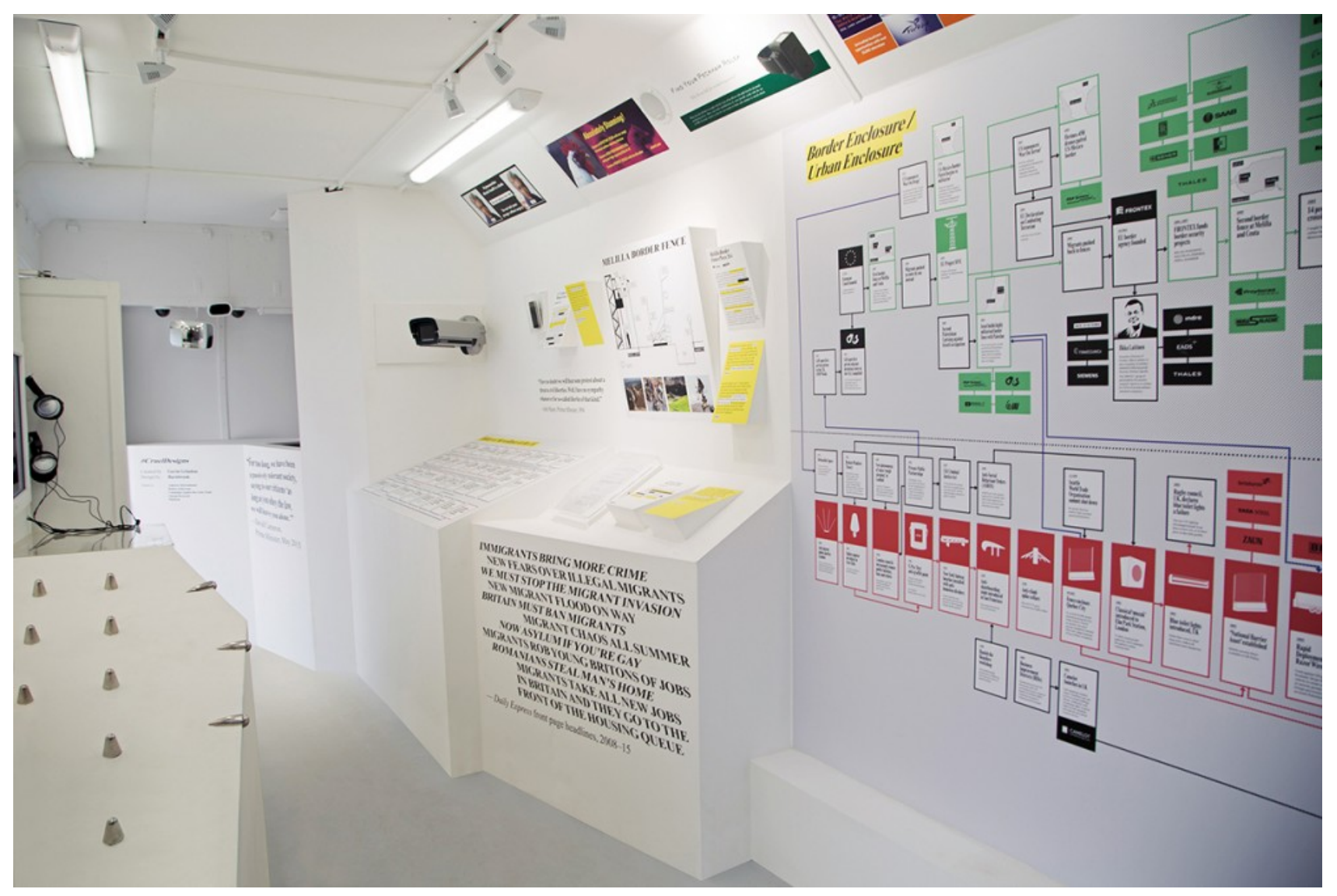

Figure 4. Cruel Designs Jonathan Barnbrook 2017

Reproduced from http://www.barnbrook.net/work/dismaland-cruel-designs/ (Accessed April 17, 2019) 


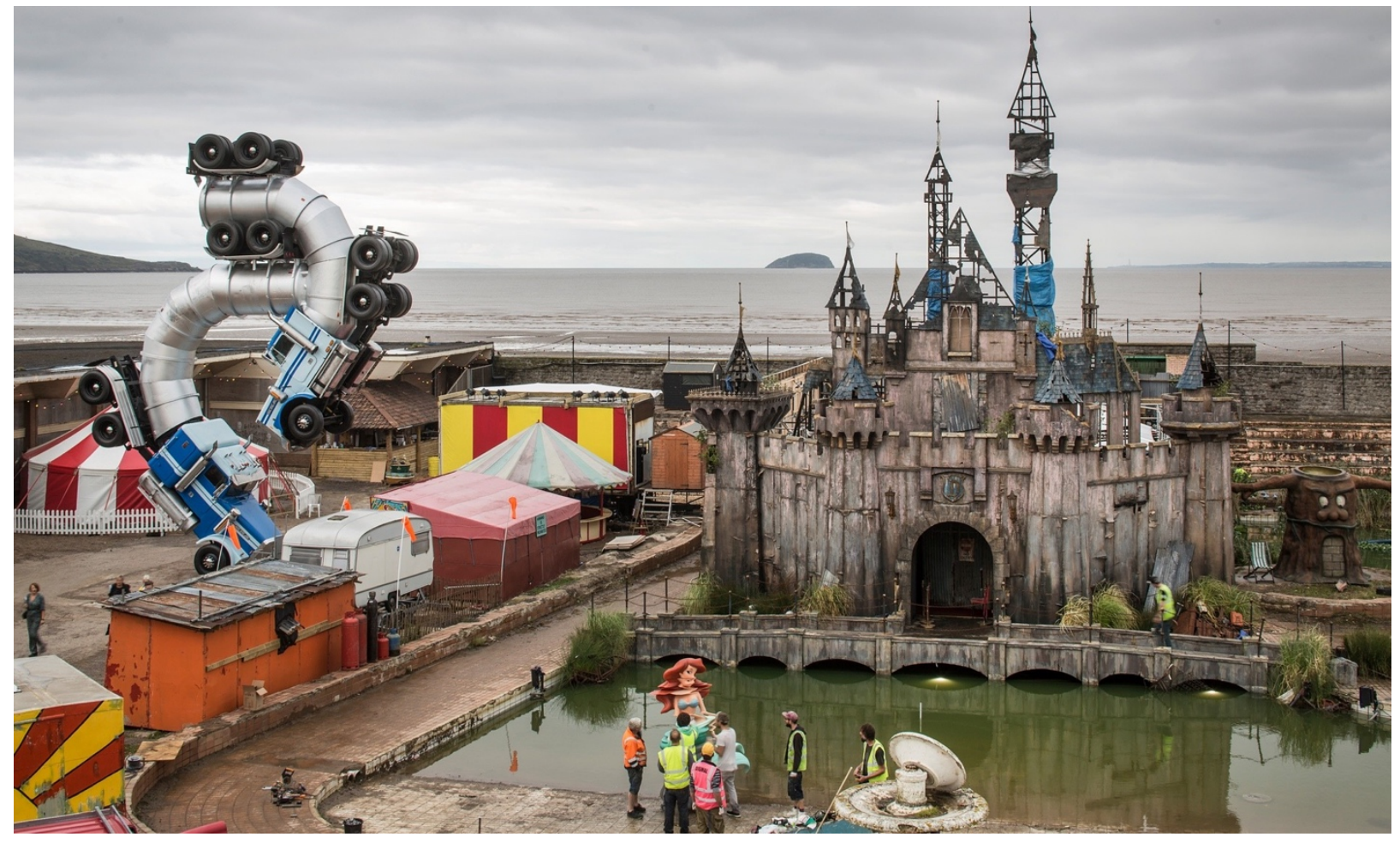

Figure 5. Dismaland

Banksy

2017

Reproduced from https://www.theguardian.com/artanddesign/2015/sep/25/banksysdismaland-closes-weston-super-mare

(Accessed April 16, 2019) 
"RUSSIAN BUSINESSMAN MINTS 'IN TRUMP WE TRUST' COIN FOR TRUMP INAUGURAL"

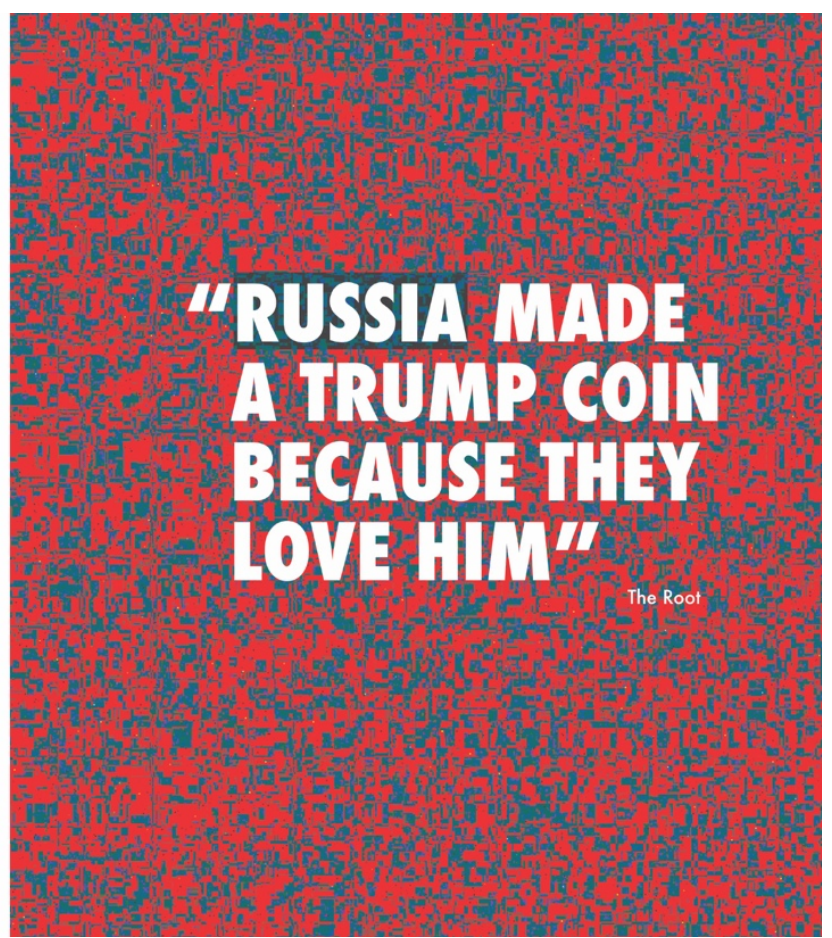

Figure 6. Kafkaesque

Zine spread

Ksenia Leshchenko

2017 


\section{Great Unsolved Mysteries in Canadian History}

Mysteries Teachers About Us Reviews News

We need your help!

A team of historians have been trying to solve some historical "cold cases" - old crimes in which the guilty ones walked, and even more insidious crimes where a whole village may have been complicit. There are other mysteries too, about unusual cases from the Viking age to the Klondike Gold Rush.

Featured Mystery

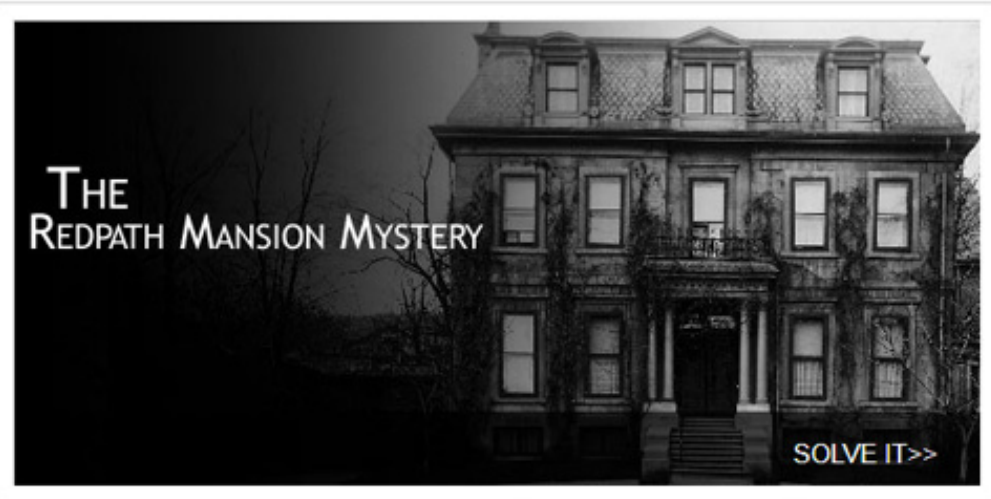

\section{Site Features}

- New - HMS Terror found

- Check out our Teachers' Guides

- Flash introductions to mysteries

- Web quest style MysteryQuests

- Curriculum Connections

- Newsletter

Figure 7. Great Unsolved Mysteries in Canadian History.

Canada's History Society

Reproduced from https://www.canadashistory.ca/awards/governor-general-s-historyawards/award-recipients/2008/great-unsolved-mysteries-in-canadian-history

(Accessed April 16, 2019) 


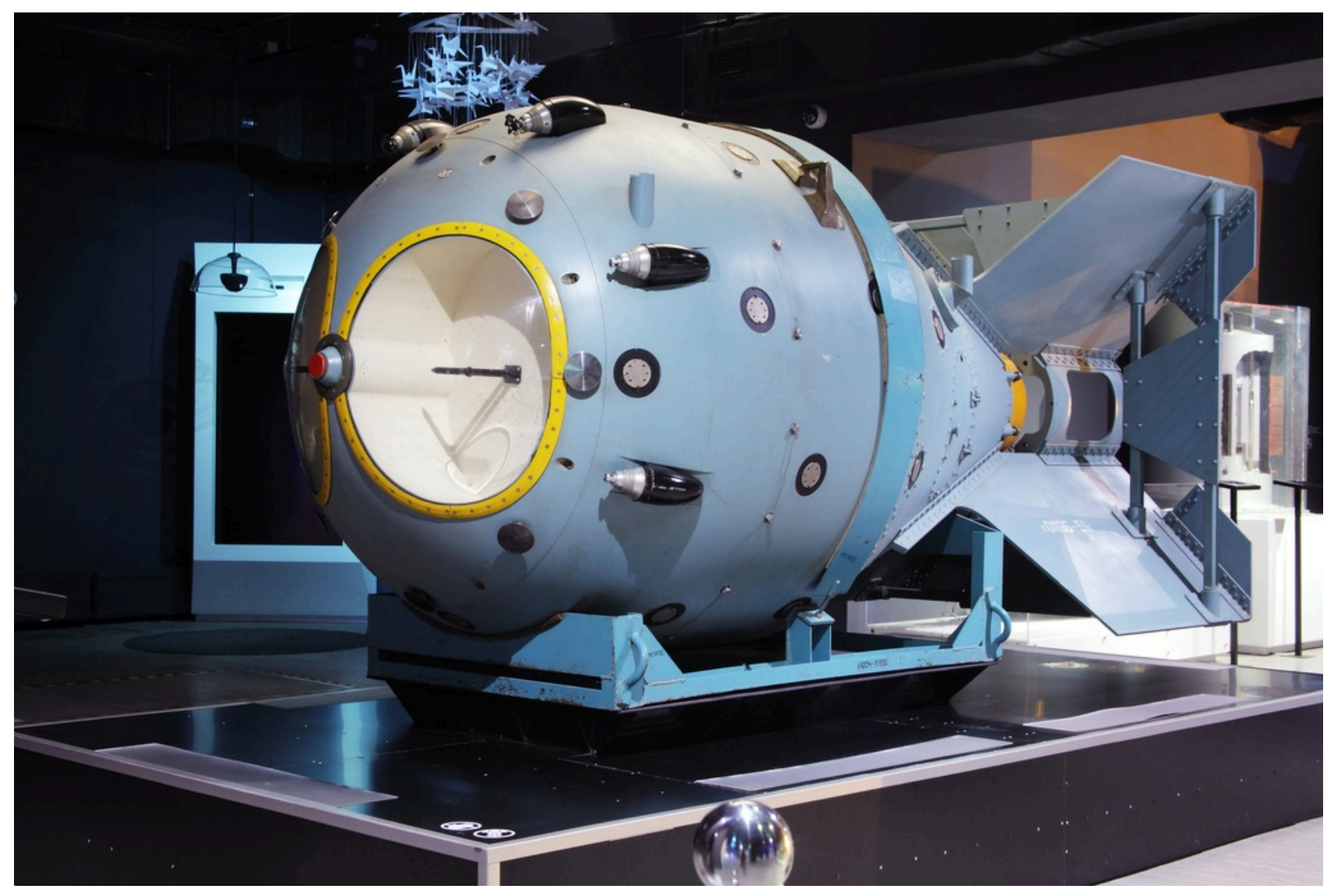

Figure 8. Soviet atomic bomb RDS-1. The Polytechnic Museum

Reproduced from https://polymus.ru/eng/current_projects/rds.html (Accessed April 17, 2019) 


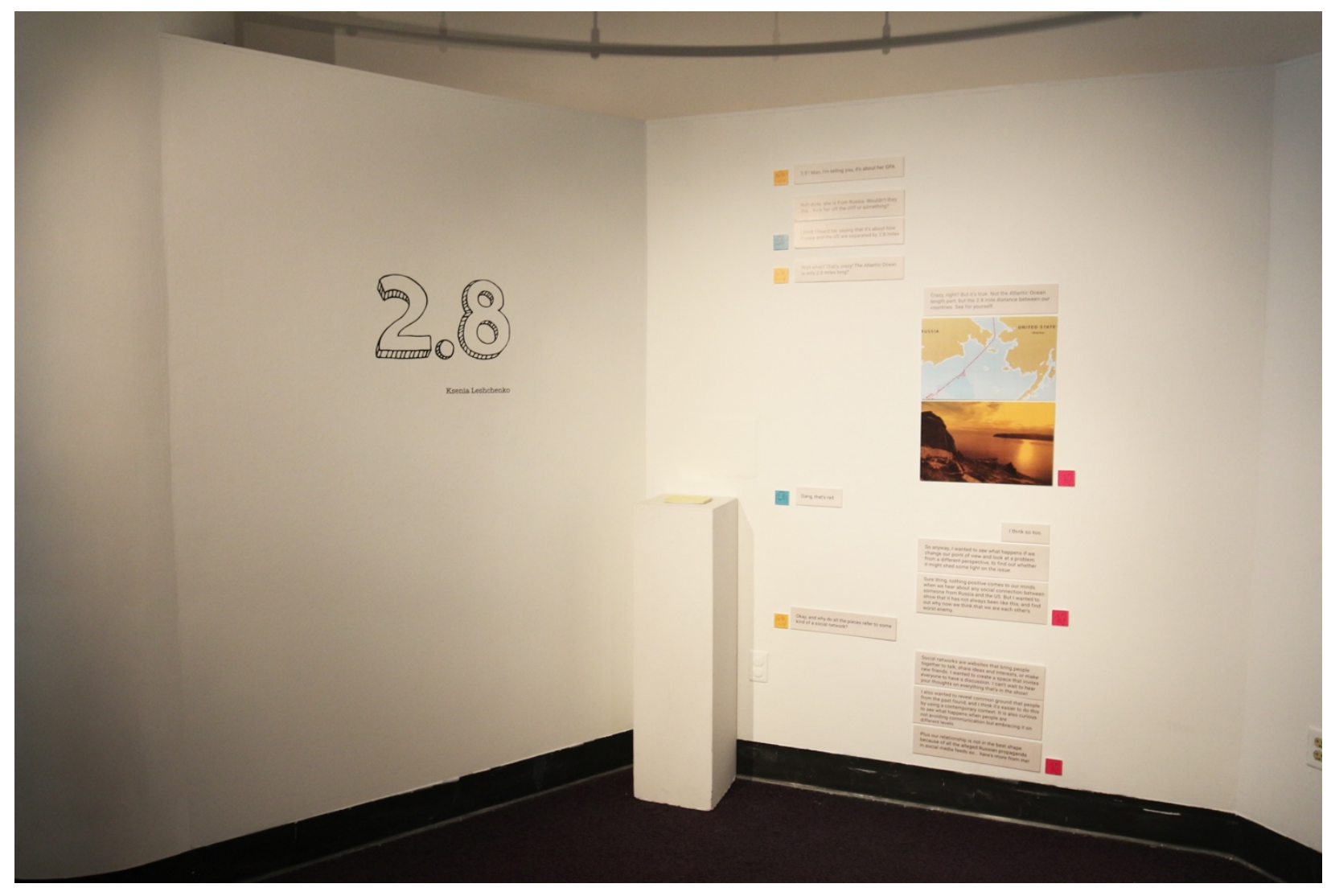

Figure 9. 2.8

Vestibule view

Paul Mesaros Gallery

2019 


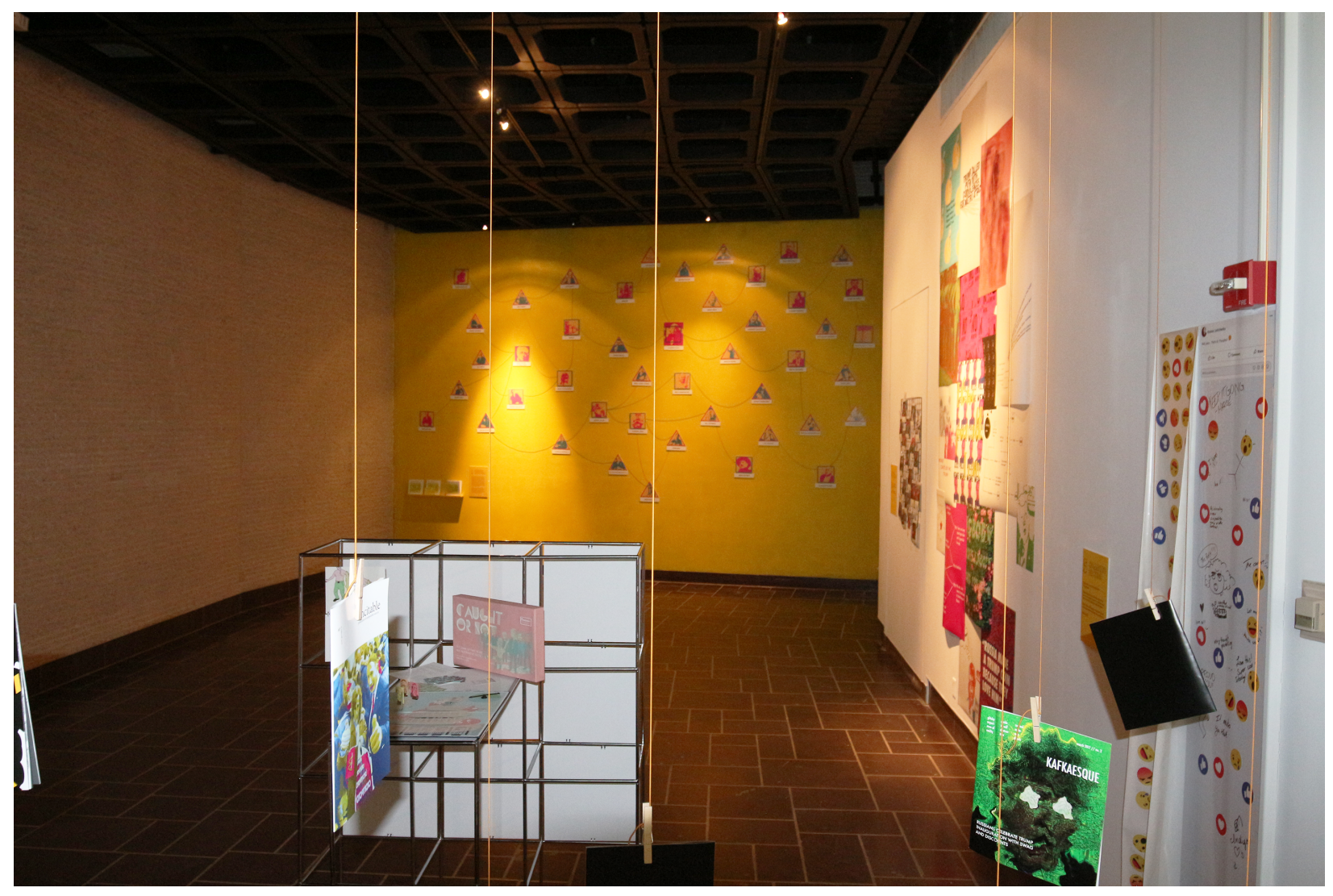

Figure 10. 2.8 Exhibition view

Paul Mesaros Gallery 2019 


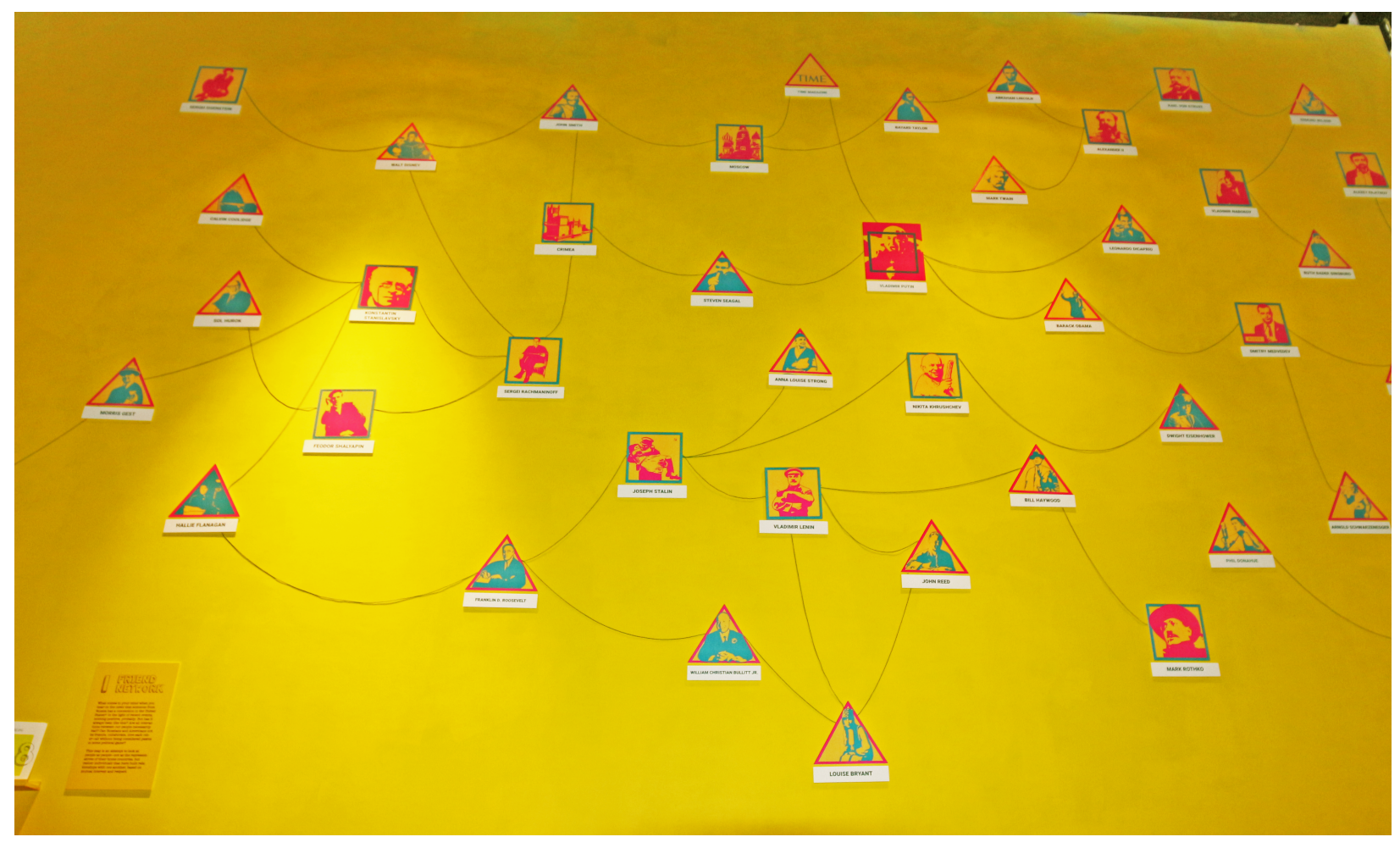

Figure 11. Friend Network

Mixed Media

2019 


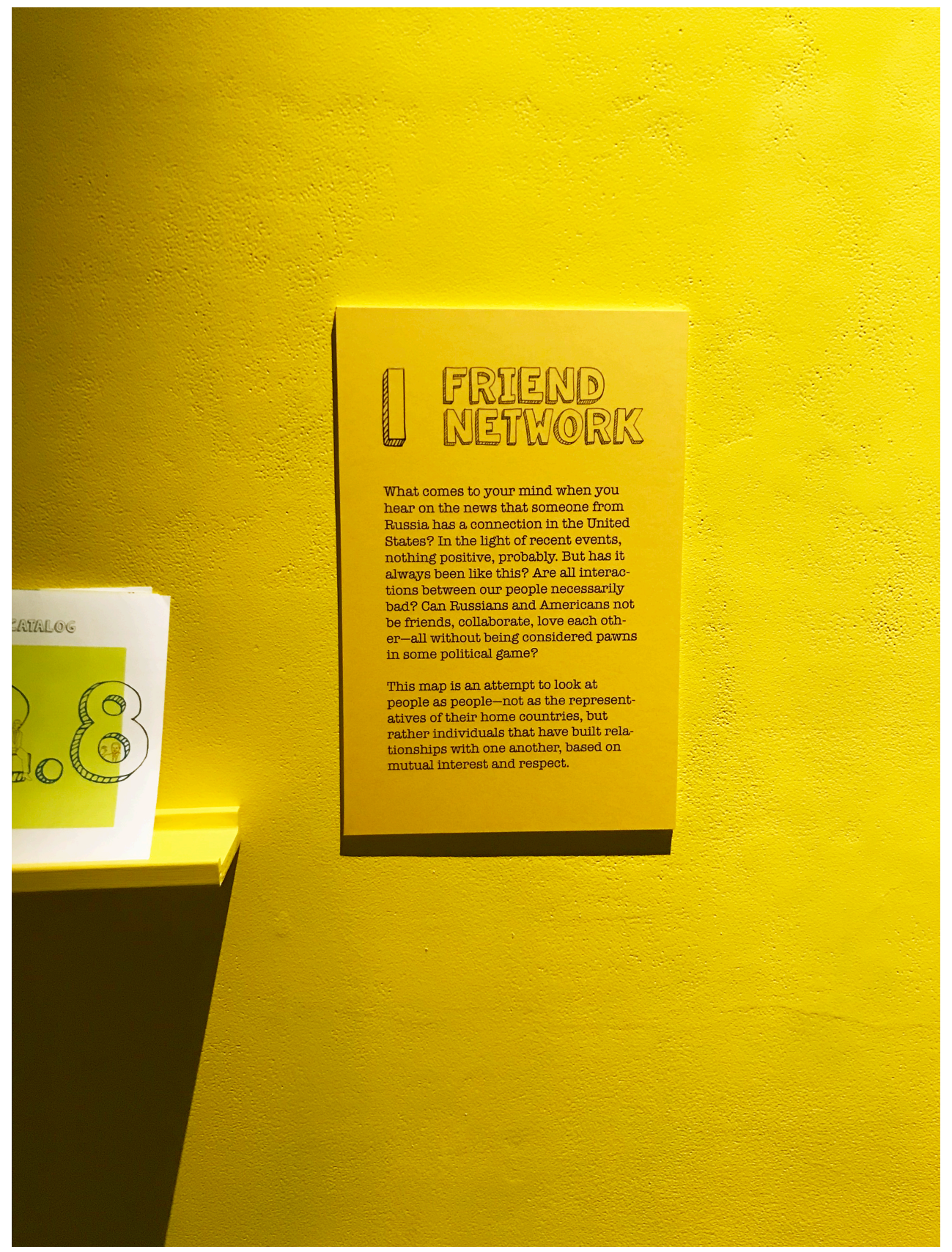

Figure 12. Friend Network Description

2019 


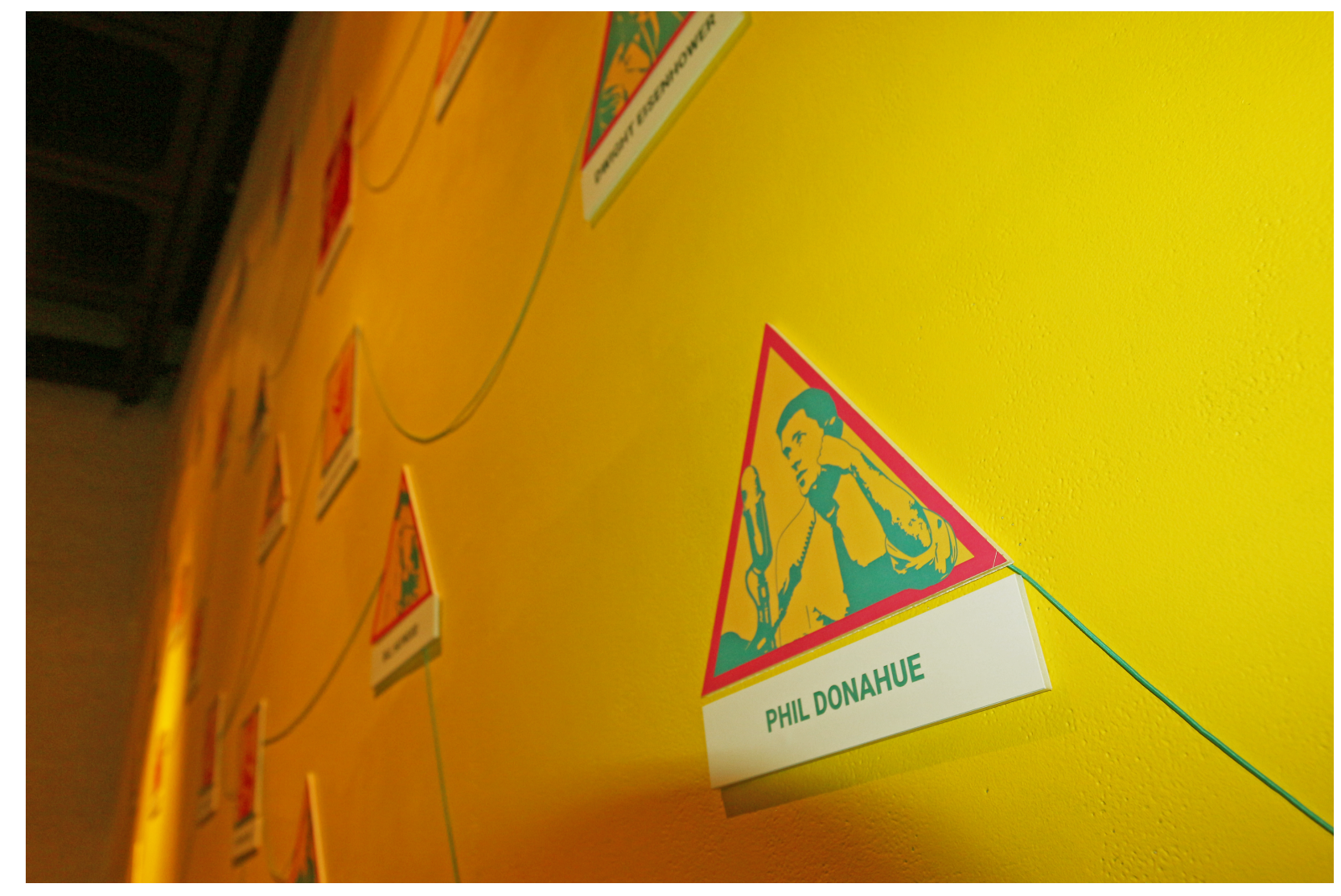

Figure 13. Friend Network

Close-up view

2019 


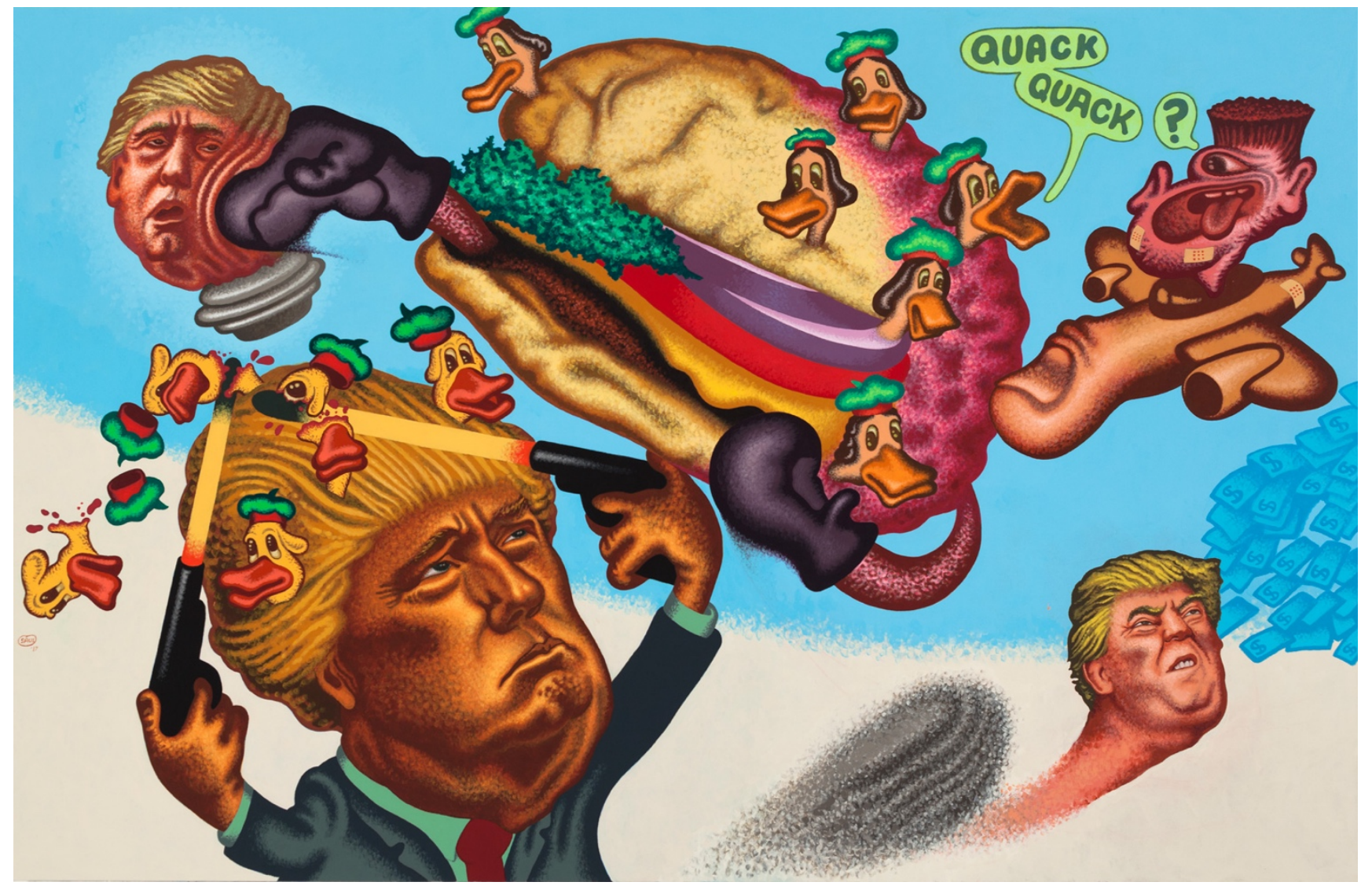

Figure 14. Quack, Quack Trump

Oil on canvas

Peter Saul

2017 


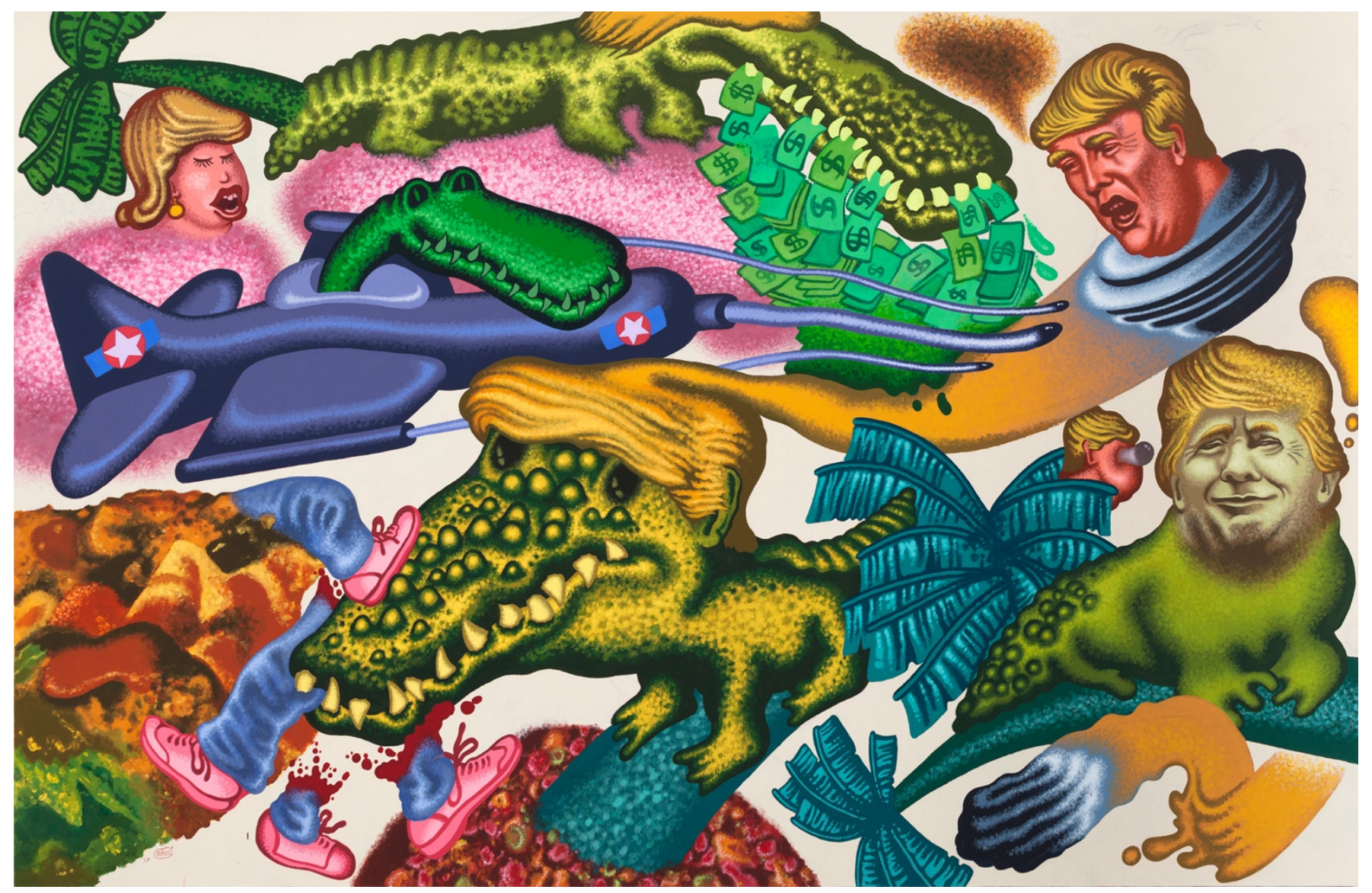

Figure 15. Donald Trump in Florida Oil on canvas Peter Saul 2017 


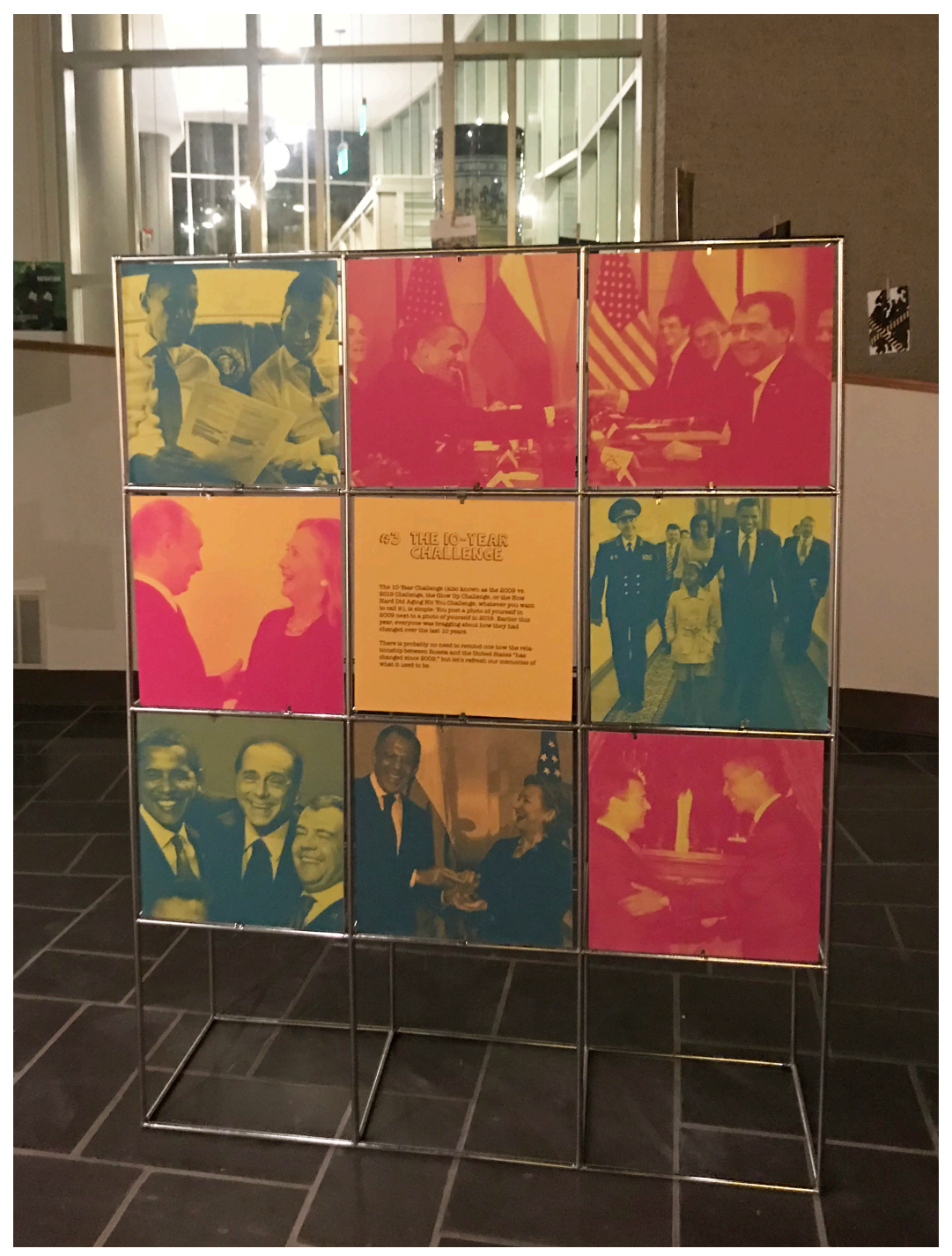

Figure 16. The 10-Year Challenge Mixed Media 2019 


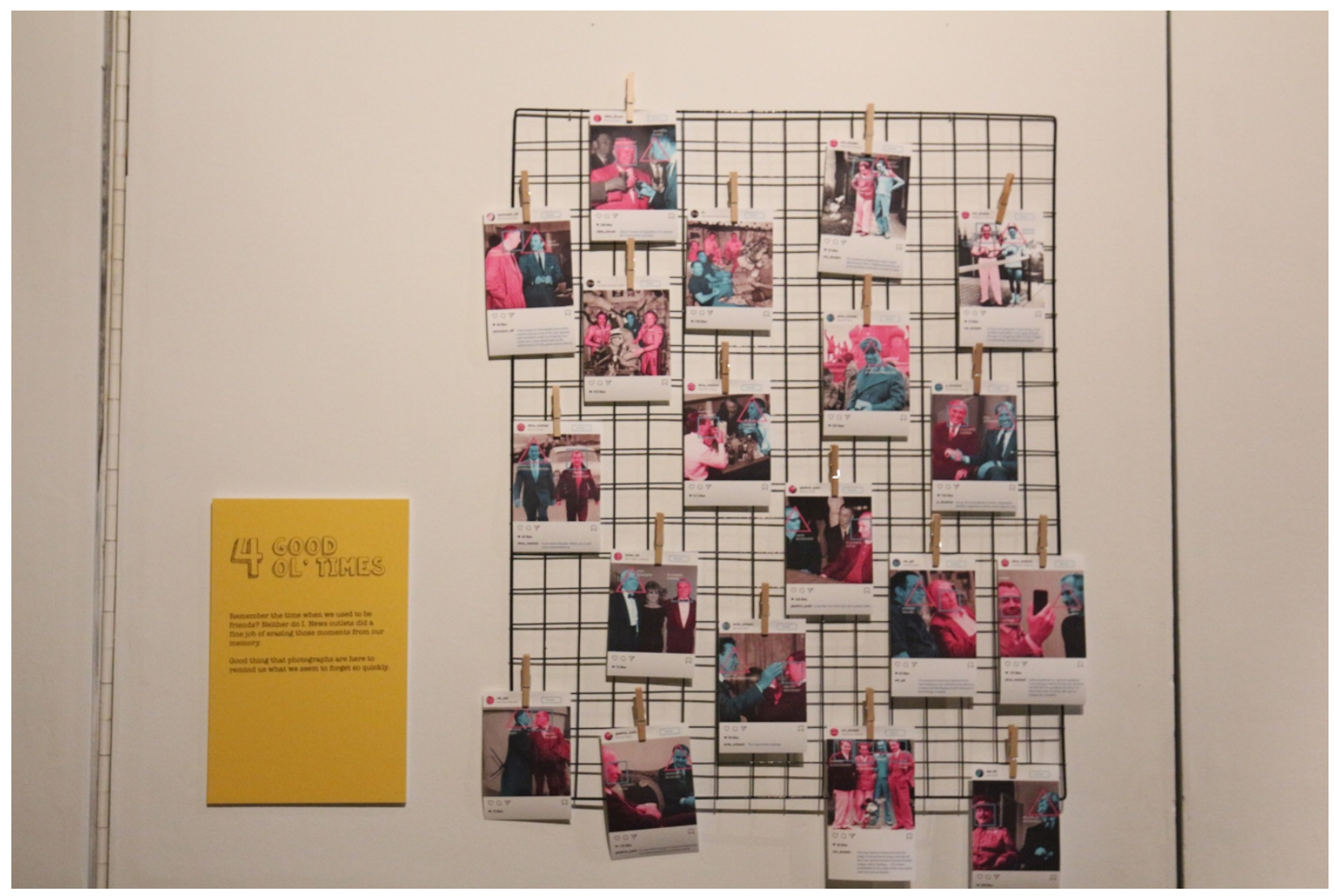

Figure 17. Good Ol' Times Mixed Media 2019 


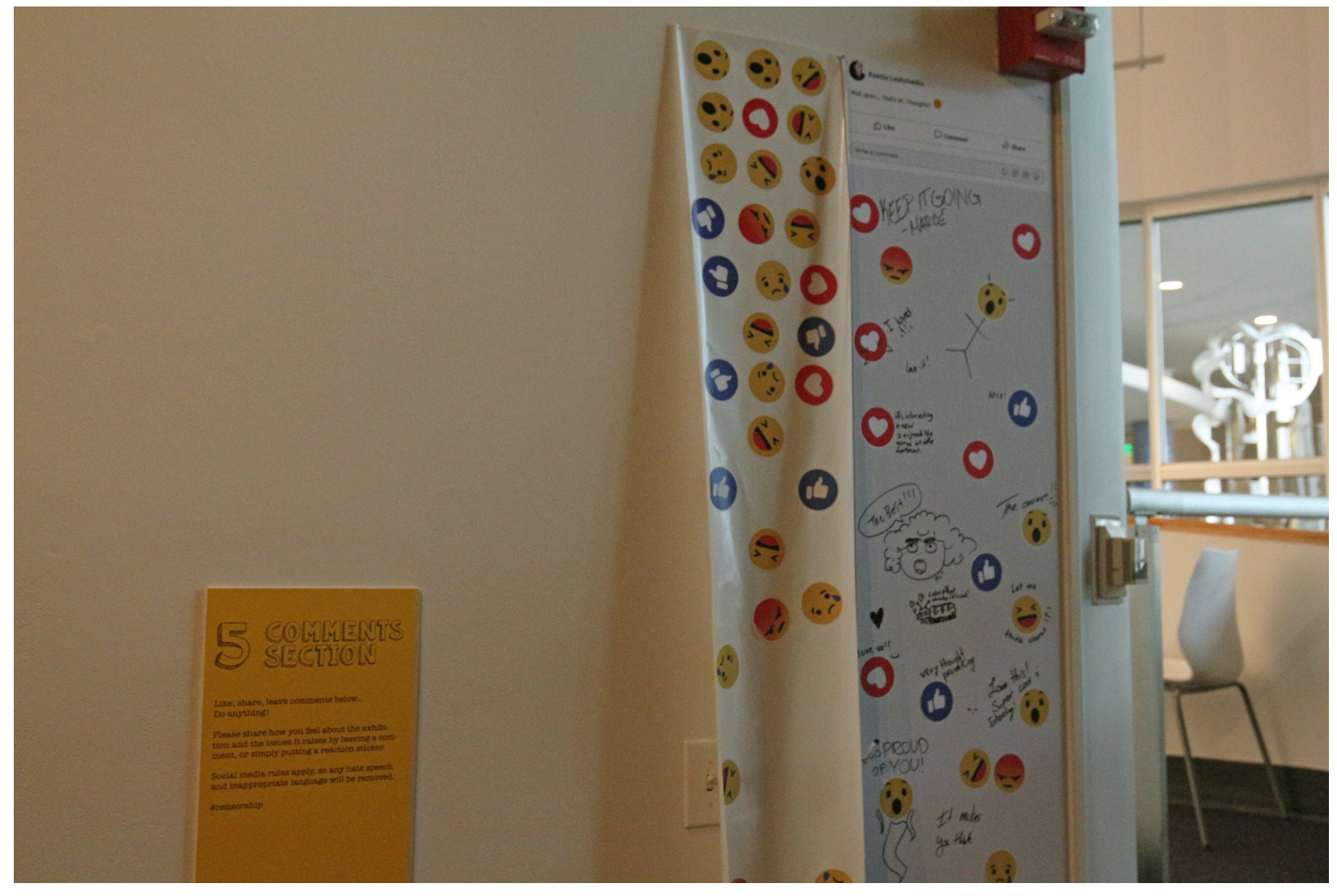

Figure 18. Comments Section Dry erase wall decal, paper 2019 


\section{BIBLIOGRAPHY}

Alexander, E. P., Mary Alexander. Museums in motion: An introduction to the history and functions of museums. Lanham: AltaMira Press, 2008.

Andersen, Margaret. "How Do You Design for an Era That's Too Absurd to Parody?". AIGA Eye on Design. March 17, 2017. Accessed November 20, 2018. https://eyeondesign .aiga.org/how-do-you-design-for-an-era-thats-too-absurd-toparody/\#:post_56256

Barnbrook, Jonathan. "Banksy's Dismaland: Cruel Designs." Barnbrook. Accessed November 20, 2018. http://www.barnbrook.net/work/dismaland-cruel-designs/

Beale, Katy. Museums at Play. Edinburgh: MuseumsEtc Ltd., 2011.

"Die Urania. Wissenschaftliche Bildung für alle Bürger zu vermitteln." UraniaBerlin. Accessed April 9, 2019. https://www.urania.de/die-urania

Fairs, Marcus. "Tucker Viemeister proposes Nazi-style logo for Donald Trump." Dezeen. January 31, 2017. Accessed November 20, 2018.

https://www.dezeen.com/2017/01/31/nazi-logo-donald-trump-tucker-viemeisterdesign-graphics-usa-news/

Falk, John H. Learning from the Museum. Walnut Creek: AltaMira Press, 2000.

Genoways, Hugh. Museum philosophy for the twenty-first century. Lanham, MD: AltaMira Press.

"Great Unsolved Mysteries in Canadian History. Recipient of the 2008 Pierre Berton Award." Canada's History. July 1, 2008. Accessed April 8, 2019.

https://www.canadashistory.ca/awards/governor-general-s-history-awards/awardrecipients/2008/great-unsolved-mysteries-in-canadian-history

Iqbal, Mansoor. "Tinder Revenue and Usage Statistics (2018)." Business of Apps. February 27, 2019. Accessed April 10, 2019.

http://www.businessofapps.com/data/tinder-statistics/

Katz, Daniel, Kenneth Braly. "Racial Prejudice and Racial Stereotypes." International Social Science Bulletin 3 (1951): 505-515.

Lippmann, Walter. Public Opinion. New York: Macmillan, 1922; rpt: Toronto: Free Press, 1965. 
Liu, Kegeng. "Designing visitor experience for open-ended creative engagement in art museums: A conceptual multi-touch prototype design." Master's thesis. lowa State University, lowa, 2013. Graduate Theses and Dissertations. 13559.

Marshall, P., Richard Morris, Yvonne Rogers, Stefan Kreitmayer, and Matt Davies. Rethinking 'multiuser': An in-the-wild study of how groups approach a walk-up-anduse tabletop interface. New York: ACM, 2011.

Metaheaven. Can Jokes Bring Down Governments? Memes, Design and Politics. Moscow, Russia: Strelka Press, 2014.

Naparat, Napapong. "Museum Exhibition: Investigating the Use of Design Elements in Narrative-oriented Exhibitions - a Case Study of the Canadian War Museum's Permanent Exhibition." Master's thesis. Carleton Univesity: Ottawa, Canada, 2010. ISBN: 978-0-494-71727-1.

Nashashibi, Salwa Mikdadi. Visitor-written labels in US art museums. Orinda: JFK University Press, 2002.

Skolnick, Lee, Jan Lorenc, What Is Exhibition Design? UK: RotoVision, 2008. 


\section{APPENDIX}

The following is a list of the collected responses from the audience left on

Comments Section:

1. Keep it going! -Marce

2. I loved it!

3. It's interesting + I really enjoyed the games.

4. Nice!

5. The coolest!

6. Caterpillar thinks it's cool.

7. The best!

8. Very thought provoking.

9. Let me think about it.

10. Love this! Super cool and interesting.

11. It makes you think.

12. Indigo.

13. It's interesting \& new. I enjoyed the games in the movement.

14. \#Bungeebooks4ever

15. So very creative and thought provoking!

16. I liked Bromance.

17. Amazing work.

18. Incredible! Really perspective changing...

19. OWO IN. 
20. So proud of you!

21. Looking forward to your next exhibition.

22. Let's all love Lain.

23. Funny, but informative! Great job!

24. As someone who doesn't know much of this stuff, the catalog was super helpful! :)

25. This made me laugh!

26. It turned out so well! Congrats Ksenia.

27. My favorite poster was the "Nobody cares about your opinion." It's really interesting, but it didn't come off as angry to me, but like a matter-of-sad fact thing.

28. Sad this has happened. Thanks for showing true humanity.

29. Очень хорошо! Спасибо!

30. It cool.

A number of collected stickers (as named on Facebook):

Like: 10

Love: 14

Haha: 4

Wow: 5

Sad: 2

Angry: 2 